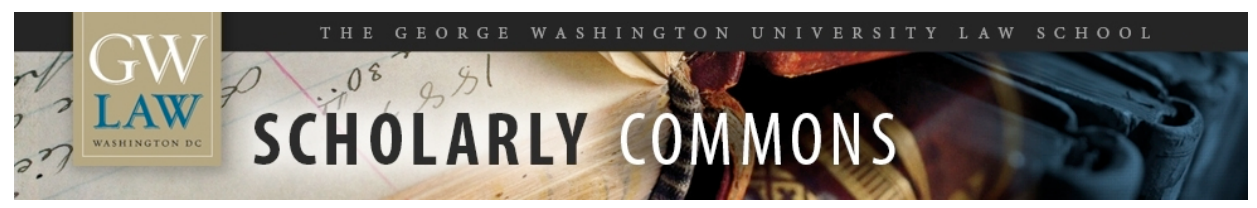

GW Law Faculty Publications \& Other Works

Faculty Scholarship

2020

\title{
The New Law of Gender Nonconformity
}

Naomi Schoenbaum

Follow this and additional works at: https://scholarship.law.gwu.edu/faculty_publications

Part of the Law Commons 


\section{Article}

\section{The New Law of Gender Nonconformity}

\section{Naomi Schoenbaum ${ }^{\dagger}$}

Introduction

I. Sex Discrimination Law as the Law of Gender Nonconformity ...839

II. Transgender Discrimination as Gender Nonconformity

Discrimination

A. Nonrecognition: Transgender Status as a Matter

of Sex

B. Recognition: A Shift from Sex to Gender

C. The Intensification of Transgender Status as Gender Nonconformity

III. The Failures of Treating Transgender Persons as Gender

Nonconformers

A. Compelling Losses

B. Pyrrhic Victories: Losing While Winning

C. Undermining Protection for Gender Nonconformity

IV. Transgender Discrimination as Sex Discrimination

A. What Bostock Gets Right: The Doctrine of Transgender Discrimination as Sex Discrimination

B. What Bostock Misses: The Theory of Transgender

Discrimination as Sex Discrimination

Conclusion

\section{INTRODUCTION}

One of the central doctrines of sex discrimination law is the protection of gender nonconformity, which bars regulated entities from requiring gender to conform to the traditional stereotypes of one's

$\dagger$ Associate Professor of Law, George Washington University School of Law. For helpful conversations and comments, I thank Michael Abramowicz, Naomi Cahn, Jessica Clarke, Katie Eyer, David Fontana, Tara Grove, Aziz Huq, Chip Lupu, Jon Michaels, Doug NeJaime, Mike Selmi, Maayan Sudai, Kate Weisburd, Deborah Widiss, Ezra Young, and participants in the George Washington University Law School Faculty Workshop and George Washington University Law School Feminist Forum seminar series. Copyright (C) 2020 by Naomi Schoenbaum. 
sex. ${ }^{1}$ The doctrine was articulated in Price Waterhouse v. Hopkins, where an employer denied a promotion to the female plaintiff Ann Hopkins because she failed to "walk more femininely, talk more femininely, dress more femininely, wear make-up, have her hair styled, and wear jewelry." 2 Hopkins challenged her employer's sex-based rule that expected women to be feminine. In deciding for the plaintiff, the Court explained how protecting gender nonconformity is key to preventing sex stereotypes from unnecessarily limiting life prospects, ${ }^{3}$ the guiding principle of sex discrimination law. ${ }^{4}$

The gender nonconformity doctrine brought a sea of change in the law of sex discrimination, ${ }^{5}$ perhaps most notably in the treatment of transgender plaintiffs. This Article uses the term transgender to refer to persons whose internal sense of their sex differs from the sex they were assigned at birth. ${ }^{6}$ After decades of denying claims of

1. See Price Waterhouse v. Hopkins, 490 U.S. 228, 251 (1989) (plurality opinion) (announcing in an employment discrimination case that "we are beyond the day when an employer could evaluate employees by assuming or insisting that they matched the stereotype associated with their group").

2. Id. at 235 (internal quotation marks omitted).

3. Id. at 251 ("An employer who objects to aggressiveness in women but whose positions require this trait places women in an intolerable and impermissible catch 22 : out of a job if they behave aggressively and out of a job if they do not.").

4. See generally Cary Franklin, The Anti-Stereotyping Principle in Constitutional Sex Discrimination Law, 85 N.Y.U. L. REv. 83 (2010) (documenting the development of sex discrimination jurisprudence as a product of anti-stereotyping aims).

5. The doctrine has been applied not only to insufficiently feminine women like Hopkins, but also to insufficiently masculine men. See, e.g., Higgins v. New Balance Athletic Shoe, Inc., 194 F.3d 252, 261 n.4 (1st Cir. 1999) (noting that the gender nonconformity doctrine protects a male plaintiff harassed by men because "just as a woman can ground an action on a claim that men discriminated against her because she did not meet stereotyped expectations of femininity ... a man can ground a claim on evidence that other men discriminated against him because he did not meet stereotyped expectations of masculinity"). The doctrine has also been applied to sexual orientation discrimination. See, e.g., Hively v. Ivy Tech Cmty. Coll. of Ind., 853 F.3d 339, 342, 346 (7th Cir. 2017) (en banc) (viewing the question "through the lens of the gender nonconformity line of cases," recognizing that "all gay, lesbian and bisexual persons fail to comply with the sine qua non of gender stereotypes-that all men should form intimate relationships only with women, and all women should form intimate relationships only with men" (quoting Hively v. Ivy Tech Cmty. Coll. of Ind., 830 F.3d 698, 709 (7th Cir. 2016))).

6. Transgender may also be used as an "umbrella" term for those whose gender identity or gender expression differs from the sex they were assigned at birth. See GLAAD MEDIA REFERENCE GUIDE 10 (10th ed. 2016), http://www.glaad.org/sites/ default/files/GLAAD-Media-Reference-Guide-Tenth-Edition.pdf [https://perma.cc/ QZ8M-KHSK]. I use it more narrowly, to mean those who identify as a different sex than that assigned at birth, as these transgender persons constitute the vast majority of plaintiffs raising sex discrimination claims. See Anna Kirkland, Victorious 
transgender discrimination as sex discrimination, ${ }^{7}$ courts began recognizing transgender discrimination as gender nonconformity discrimination on the theory that a transgender person who adopts a gender presentation that fails to conform to sex designated at birth is a gender nonconformer. ${ }^{8}$ As one court explained, discrimination against a transgender person designated male at birth who adopts a feminine gender performance should be understood as discrimination due to the "failure to conform to sex stereotypes concerning how a man should look and behave."

The Supreme Court faced the new law of gender nonconformity this term in Bostock v. Clayton County, Georgia, which considered whether the firing of Aimee Stephens on the basis of her transgender status was sex discrimination under federal employment discrimination law. ${ }^{10}$ The Court held that it was, but did so without relying on the gender nonconformity theory, notwithstanding that this was the theory on which Stephens ${ }^{11}$ and the lower courts in her case relied;12 a

Transsexuals in the Courtroom: A Challenge for Feminist Legal Theory, 28 LAW \& Soc. INQUIRY 1, 29 (2003) (describing this as "the most common form" of transgender identity). And this is how most courts have understood the term. See infra Parts II.A and II.B for a discussion of these cases. I do briefly address the broader range of transgender identity. See infra notes 258-65, 310-13 and accompanying text.

7. See infra Part II.A.

8. See infra Part II.B.

9. Smith v. City of Salem, 378 F.3d 566, 572 (6th Cir. 2004).

10. Bostock v. Clayton Cnty., 140 S. Ct. 1731 (2020). The Court consolidated several cases, Stephens's among them, to consider whether transgender discrimination and sexual orientation discrimination amount to sex discrimination. It answered both questions in the affirmative. See id. at 1737.

11. Brief for Respondent Aimee Stephens at 29, R.G. \& G.R. Harris Funeral Homes, Inc. v. Equal Emp. Opportunity Comm'n (Harris III), 140 S. Ct. 1731 (2020) (mem.) (No. 18-107), 2019 WL 2745392 ("Harris Homes discriminated against Ms. Stephens because she departed from its owner's expressly articulated stereotypes about how men and women should identify, appear, and behave."). Stephens and a number of amici also relied on a textual argument in a way that lower courts had not. See, e.g., id. at 20 (arguing that "fir[ing] [Stephens] for (1) having a male sex assigned at birth and (2) living openly as a woman," is sex discrimination "[b]ecause [the employer] would not have fired Ms. Stephens for ... living openly as a woman if she were assigned a female sex at birth"); Brief of Statutory Interpretation and Equality Law Scholars as Amici Curiae in Support of the Employees at 4, Bostock, 140 S. Ct. 1731 (Nos. 17-1618, 17-1623, 18-107), 2019 WL 2915037 ("The text of Title VII plainly prohibits employment discrimination based on an individual's sexual orientation or transgender status.").

12. Equal Emp. Opportunity Comm'n v. R.G. \& G.R. Harris Funeral Homes, Inc. (Harris II), 884 F.3d 560, 576 (6th Cir. 2018) (holding for the employee because a "transgender person is ... inherently 'gender non-conforming"'); Equal Emp. Opportunity Comm'n v. R.G. \& G.R. Harris Funeral Homes, Inc. (Harris I), 201 F. Supp. 3d 837, 849-51 (E.D. Mich. 2016) (noting the "direct evidence" of employment discrimination in Stephen's termination due to her "failure to conform to sex stereotypes"). 
theory broadly adopted by lower courts; ${ }^{13}$ and a theory generally celebrated by scholars ${ }^{14}$ and advocates ${ }^{15}$ of transgender rights. Bostock is a victory not only for validating transgender rights, but for doing so without relying on the gender nonconformity theory. ${ }^{16}$ This is so

13. See infra notes $110-11$ and accompanying text.

14. See, e.g., Mary Anne C. Case, Disaggregating Gender from Sex and Sexual Orientation: The Effeminate Man in the Law and Feminist Jurisprudence, 105 YALE L.J. 1, 4 (1995); Katherine M. Franke, The Central Mistake of Sex Discrimination Law: The Disaggregation of Sex from Gender, 144 U. PA. L. REV. 1, 95-96 (1995); Laura Grenfell, Embracing Law's Categories: Anti-Discrimination Laws and Transgenderism, 15 YALE J.L. \& FEMINISM 51, 61-62 (2003); Kirkland, supra note 6, at 25-30; Ilona M. Turner, Sex Stereotyping Per Se: Transgender Employees and Title VII, 95 CALIF. L. REv. 561, 563 (2007). But see Kimberly A. Yuracko, Soul of a Woman: The Sex Stereotyping Prohibition at Work, 161 U. PA. L. REV. 757, 795 (2013) (arguing that the application of the gender nonconformity doctrine to transgender discrimination encourages stereotypical gender performance).

To the extent that scholars have criticized courts' understanding of transgender discrimination as sex discrimination, they have placed the blame on advocates or judges, rather than on the doctrine itself. See Ezra Ishmael Young, What the Supreme Court Could Have Heard in R.G. \& G.R. Harris Funeral Homes v. EEOC and Aimee Stephens, 11 CALIF. L. REV. ONLINE 9, 11 (2020) (placing blame on "progressive litigators and theorists" because, in part, they "framed [transgender women's claims] as if they were not women"); Alexander Chen, The Supreme Court Doesn't Understand Transgender People, SLATE (Oct. 18, 2019, 3:11 PM), https://slate.com/news-and -politics/2019/10/supreme-court-transgender-discrimination-sex.html [https:// perma.cc/2E6F-U9JU] (critiquing the Supreme Court and Stephens's lawyer for viewing Stephens as a man but claiming that "[s]ince the early $2000 \mathrm{~s}, \ldots$ transgender litigants" have succeeded in "the lower courts by fully embracing the reality of transgender identity").

15. See, e.g., Brief of the National Women's Law Center and Other Women's Rights Groups as Amici Curiae in Support of the Employees at 20, Bostock, 140 S. Ct. 1731 (Nos. 17-1618, 17-1623, 18-107), https://www.supremecourt.gov/DocketPDF/17/17 -1618/107019/20190710162958207_tsac\%20National\%20Womens\%20Law\% 20Center\%20Corrected.pdf [https://perma.cc/6WEL-VYRX] (arguing that transgender discrimination is sex discrimination because " $[t]$ ransgender people transgress the expectation that one identify with and adopt the social roles and behaviors of one's sex assigned at birth"); Brief of Employment Discrimination Law Scholars as Amici Curiae in Support of the Employees at 23, Bostock, 140 S. Ct. 1731 (Nos. 17-1618, 17-1623, 18-107) 2019 WL 2915043 ('Title VII's anti-stereotyping principle ... readily applies to cases, such as these, in which an employer fires a lesbian, gay, bisexual, or transgender (LGBT) individual for not acting in accord with sex stereotypes, i.e., beliefs about how men or women should act."). See generally Docket, R.G. \&. G.R. Harris Funeral Homes, Inc. v. Equal Emp. Opportunity Comm'n, 140 S. Ct. 1731 (2020) (No. 18-107), https://www.supremecourt.gov/docket/docketfiles/html/public/18 -107.html [https://perma.cc/N2TF-VZ54] (cataloguing dozens of amicus briefs in support of the plaintiff prevailing on this theory).

16. Bostock, $140 \mathrm{~S}$. Ct. at 1741 (holding that "it is impossible to discriminate against a person for being ... transgender without discriminating against that individual based on sex," because "an employer who fires a transgender person who was identified as a male at birth but who now identifies as a female," but "retains an otherwise 
because transgender discrimination is not gender nonconformity discrimination. Treating it as such is not only analytically incorrect, but also does serious damage to the cause of sex equality, by unnecessarily undermining transgender rights and protection for gender nonconformity. Transgender discrimination is sex discrimination, but only on an alternative theory based in transgender persons' sex, not their gender: that discriminating against a transgender person necessarily entails considering their sex assigned at birth. ${ }^{17}$

Numerous harms are associated with treating transgender persons as gender nonconformers. Sometimes, it compels losses. Rather than challenge sex-based rules, like Hopkins and other gender nonconformers of the past, some transgender plaintiffs seek rights under them. For example, in the lower courts, Aimee Stephens's lawsuit turned on her rights under her employer's sex-segregated dress code. ${ }^{18}$ She did not seek to invalidate the dress code; she wanted to be treated as a woman under it. ${ }^{19}$ These are not cases where transgender persons are discriminated against because of a failure to conform their gender to their sex assigned at birth. Instead, these are cases where transgender persons are discriminated against because of what their sex assigned at birth is. Transgender plaintiffs have lost these cases because the doctrine has nothing to say about sex-based rules

identical employee who was identified as female at birth ... intentionally penalizes a person identified as male at birth for traits or actions that it tolerates in an employee identified as female at birth").

17. See id.

18. See Harris I, 201 F. Supp. 3d 837, 861 (E.D. Mich. 2016) (noting that "the EEOC takes the position that Stephens has the right, under Title VII, to 'dress as a woman'”). At the Supreme Court, there was some dispute about the factual basis for Stephens's termination: the violation of the dress code, her transgender status, or both. Transcript of Oral Argument at 22-23, R.G. \& G.R. Harris Funeral Homes, 140 S. Ct. 1731 (No. 18107) ("[T]here seems ... to be this dispute among the parties in this case as to what the basis of the firing was, whether the basis of the firing was the-the violation of the dress code, particularly, or whether it was broader than that, was being transgender." (quoting Kagan, J.)). The Court decided that "[t]he only question before us is whether an employer who fires someone simply for being ... transgender has discharged or otherwise discriminated against that individual 'because of such individual's sex.'” Bostock, $140 \mathrm{~S}$. Ct. at 1753.

19. See, e.g., Harris II, 884 F.3d 560, 573 (6th Cir. 2018) (finding that "whether certain sex-specific appearance requirements violate Title VII ... is not before this court," and thus that "[w] are not considering, in this case, whether the Funeral Home violated Title VII by requiring men to wear pant suits and women to wear skirt suits"). For some examples of cases that discuss sex discrimination based on gender nonconformity, see infra note 111 . 
that go unchallenged. Indeed, Stephens ultimately lost in the district court for this reason. ${ }^{20}$

This shortcoming of the gender nonconformity doctrine is no small thing. There is still quite a long list of areas aside from bathrooms and dress codes that are lawfully sex segregated, including education, the military, prisons, and athletics. ${ }^{21}$ As transgender persons seek access to more sex segregated spaces based on their identified sex, the error of addressing transgender discrimination under this doctrine will only compound.

Not only is the gender nonconformity doctrine inadequate to address access to sex-based rules, but its application is harmful even in the gender performance cases transgender plaintiffs have won. By treating transgender persons as gender nonconformers, courts reify transgender persons' birth-designated sex as their legal sex. Under the gender nonconformity theory, a transgender person designated male at birth is an effeminate man, not a woman; a transgender person designated female at birth is a masculine woman, not a man. ${ }^{22}$ This view of the sex of transgender persons is contested, and is contrary to transgender persons' own identity ${ }^{23}$ and to substantial medical ${ }^{24}$ and legal authority. ${ }^{25}$ And it undermines the position of transgender plaintiffs seeking access to sex-based rules. So even when individual plaintiffs win under this theory, these Pyrrhic victories amount to a defeat for the broader cause of transgender rights.

Treating transgender persons as gender nonconformers also undermines protection for gender nonconformity. Under the doctrine,

20. Harris I, 201 F. Supp. 3d 837, 861 (E.D. Mich. 2016) ("The only reason that the EEOC can pursue a Title VII claim on behalf of Stephens in this case is under the theory that the Funeral Home discriminated against Stephens because Stephens failed to conform to the 'masculine gender stereotypes that [the owner] expected' in terms of the clothing Stephens would wear at work.... Yet the EEOC has not challenged the Funeral Home's sex-specific dress code."). See infra notes 285-92 for a discussion of how the district court's confusion about Stephens's dress-code claim under the gender nonconformity doctrine led the employer to prevail on a religious freedom defense.

21. See generally David S. Cohen, The Stubborn Persistence of Sex Segregation, 20 COLUM. J. GENDER \& L. 51, 55, passim (2011) (noting that "[h]undreds of laws in the United States segregate based on sex" and documenting them).

22. See infra notes 141-43 and accompanying text.

23. See, e.g., Harris II, 884 F.3d at 568 (quoting letter from transgender plaintiff designated male at birth seeking to be recognized as female indicating that "she has 'decided to become the person that [her] mind already is'"' (alteration in original)).

24. See infra notes $161-78,185$ and accompanying text.

25. See infra notes $179-84$ and accompanying text. 
claims brought by cisgender ${ }^{26}$ persons like Hopkins appear weak next to transgender claims. Cisgender plaintiffs are seen as less gender nonconforming. Their claims don't enjoy the support of objective medical evidence and, by seeking to dismantle rather than access sexrespecting rules, they pose a greater threat to the existing sex-based order and to institutional discretion. ${ }^{27}$ While scholars have explored the relative weakness of cisgender as compared with transgender nonconformity claims, ${ }^{28}$ they have not identified the source of the problem that this Article does: wrongly treating transgender plaintiffs as gender nonconformers in the first place.

This Article not only identifies these harms but also locates their source in the judicial confusion of sex and gender. The Article traces how courts came to wrongly understand being transgender as a matter of gender rather than sex and thus treated transgender plaintiffs as gender nonconformers. This Article thus picks up the jurisprudential ground left off by one of the seminal articles on sex discrimination law, which located the shortcomings of the original law of gender nonconformity in the law's confusion of sex and gender. ${ }^{29}$ A quarter century later, this Article echoes the same call: courts are continuing to confuse sex and gender under the new law of gender nonconformity. Correcting this confusion is essential to fulfilling sex discrimination law's promise of equality.

Bostock begins to show the way forward. Across sex discrimination law, courts should adopt a theory of transgender discrimination grounded in sex rather than gender. While Bostock avoids the

26. This is the term for persons whose identified sex matches their sex designated at birth, in contrast to transgender persons. See GLAAD MEDIA REFERENCE GUIDE, supra note 6 , at 11 .

27. See infra Part III.C.

28. See Mary Anne Case, Legal Protections for the "Personal Best" of Each Employee: Title VII's Prohibition on Sex Discrimination, the Legacy of Price Waterhouse v. Hopkins, and the Prospect of ENDA, 66 STAN. L. REV. 1333, 1352 (2014) ("[A]s courts relying on Hopkins became more receptive to claims by ... transgender plaintiffs, they paradoxically became less receptive to plaintiffs who more closely resembled Ann Hopkins herself ...."); Yuracko, supra note 14, at 794-95 (explaining that under the gender nonconformity doctrine, as compared with the success of transgender plaintiffs, "those who do not seek to switch [sex] categories but instead to reject discrete aspects of their prescribed gender code while maintaining conformity with others... will (continue to) lack protection").

29. See Case, supra note 14, at 2 (explaining that "[ $\mathrm{t}$ ] he word 'gender' has come to be used synonymously with the word 'sex' in the law of discrimination" and that "[w]ere that distinct meaning of gender [as a cultural rather than a biological phenomenon] to be recaptured in the law, great gains both in analytic clarity and in human liberty and equality might well result"). For further discussion, see infra notes 102-09 and accompanying text. 
problems associated with the gender nonconformity doctrine, it falls short by failing to connect the problem of transgender discrimination to the problem of sex discrimination, and, indeed, suggests the opposite: that they are distinct phenomena without a social relationship. 30 This is wrong. Much transgender discrimination is motivated by the same sex stereotypes that have long been recognized to hold women and men back at work. A person who is designated male at birth is viewed as too masculine to be a woman; a person who is designated female at birth is viewed as too feminine to be a man. ${ }^{31}$ So, contrary to the concerns of some commentators and courts, recognizing transgender discrimination as sex discrimination furthers the antistereotyping aims of sex discrimination law. 32

Bostock's failure to connect transgender discrimination to the broader concerns animating sex discrimination law matters legally and socially. Legally, the failure to ground transgender discrimination more deeply in fundamental government interests combatting core sex discrimination problems risks weakening transgender plaintiffs' sex discrimination claims against religious freedom defenses. ${ }^{33}$ Indeed, Stephens lost in the district court to such a defense because the court failed to appreciate how her claim helped to further the anti-stereotyping goals of sex discrimination law. ${ }^{34}$ Socially, commentators have raised concerns that transgender persons reinforce rather than challenge sex stereotypes that harm women, driving a wedge between those supporting transgender rights on the one hand and women's rights on the other. ${ }^{35} \mathrm{~A}$ decision that distinguishes between these forms of discrimination rather than illuminating how the same stereotypes animate both undermines solidarity. It is crucial for courts to correct this error of Bostock and make clear how fighting transgender discrimination helps to fight stereotypes in just the way sex discrimination law has long sought to do.

30. See infra notes 267-82 and accompanying text.

31. As discussed in more detail below, see infra notes 325-27 and accompanying text, the best example is also perhaps the highest profile: the case of Olympic athlete Caitlyn Jenner.

32. See infra notes 306-26 and accompanying text; Naomi Schoenbaum, The Supreme Court Victory for Transgender Women Is a Win for All Women, SLATE (June 15, 2020, 6:38 PM), https://slate.com/news-and-politics/2020/06/supreme-court -transgender-women-aimee-stephens-victory.html [https://perma.cc/E7W8-UE74].

33. See infra notes 283-300 and accompanying text.

34. See Harris I, 201 F. Supp. 3d 837, 863 (E.D. Mich. 2016) (explaining that the "position that Stephens must be allowed to wear a skirt-suit" amounts to a claim that Stephens should "be able to dress in a stereotypical feminine manner").

35. See infra notes 303-09 and accompanying text. 
This Article proceeds in four parts. The first two parts are descriptive. Part I describes the "old" law of gender nonconformity, setting forth why and how sex discrimination law protects against discrimination on this basis. Part II traces the development of the new law of gender nonconformity, documenting courts' initial rejection of transgender discrimination as sex discrimination and the shift towards recognition, highlighting how the shift involved not only a change in law but also a change in the judicial view of transgender status. Part III shifts to the normative, explaining the errors of the new law of gender nonconformity and the harms that flow therefrom. Part IV charts the way forward, showing how Bostock's textual approach to treating transgender discrimination as sex discrimination avoids the harms of the gender nonconformity doctrine, yet also instantiates new failings, and suggests how to correct them.

\section{SEX DISCRIMINATION LAW AS THE LAW OF GENDER NONCONFORMITY}

For most of American history, the life and law of the sexes was one of separate spheres, each of which placed sex-specific demands and expectations on its inhabitants: for men, "to be breadwinner, head of household, representative of the family outside the home" and for women, "not only to bear, but also to raise children, and keep the home in order." 36 These "respective spheres" contained a constellation of assumptions and expectations of gender that were viewed as consistent with appropriate sex roles. ${ }^{37}$

Sex discrimination law has aimed to dismantle the legal, social, and economic infrastructure that has animated and policed these sexspecific expectations. Once it was recognized that "the sex characteristic frequently bears no relation to ability to perform or contribute to society," 38 scrutiny of sex-based rules and decisions was important to dismantle a "broad[] pattern of sex-role enforcement" that unnecessarily limited opportunities by sex. ${ }^{39}$ Sex discrimination law

36. Ruth Bader Ginsburg, Remarks on Women Becoming Part of the Constitution, 6 LAW \& INEQ. 17, 19 (1988); see also Sessions v. Morales-Santana, 137 S. Ct. 1678, 1689 (2017) (referencing "an era when the lawbooks of our Nation were rife with overbroad generalizations about the way men and women are").

37. Women were "natural[ly] and proper[ly] timid[] and delica[te]," and thus "unfit for many of the occupations of civil life," whereas men were strong and invulnerable, and thus were properly fit to serve in roles in public life and as "woman's protector and defender." Bradwell v. Illinois, 83 U.S. 130, 141 (1872) (Bradley, J., concurring).

38. Frontiero v. Richardson, 411 U.S. 677, 686 (1973).

39. Franklin, supra note 4, at 124; see also Frontiero, 411 U.S. at 684 (invalidating a law presuming wives of male service members were economically dependent on 
distinguishes between the valid reliance on sex differences as compared with the invalid reliance on stereotypes about gendered behavior. ${ }^{40}$ From caregiving fathers, ${ }^{41}$ to working mothers, ${ }^{42}$ to women in non-traditional jobs, ${ }^{43}$ gender nonconformers have long successfully challenged sex-based rules and decisions assuming traditional gendered behavior, freeing men to act in "feminine" ways and women to act in "masculine" ways.

Despite rigorous scrutiny of sex-based rules and decisions for the influence of stereotypes, not all sex-based rules and decisions fail this bar. We can see legal sex classifications in the realms of prisons, ${ }^{44}$ education, ${ }^{45}$ the military, ${ }^{46}$ and bathrooms, ${ }^{47}$ to cite just a few examples, ${ }^{48}$ and a host of sex classifications have withstood judicial scrutiny. ${ }^{49}$ Many scholars, myself included, have argued that more sex-

their husbands but not affording same presumption to husbands of female service members as part of "a long and unfortunate history of sex discrimination ... rationalized by an attitude of 'romantic paternalism' which, in practical effect, put women, not on a pedestal, but in a cage").

40. United States v. Virginia, 518 U.S. 515, 533, 550 (1996) (striking down the male-only admissions policy to a military institute as an "overbroad generalization" based in and furthering harmful sex stereotypes, rather than justified by "inherent differences" between men and women, because some women could fulfill the standard); L.A. Dep't of Water \& Power v. Manhart, 435 U.S. 702, 707 n.13 (1978) (noting that "[i]t is now well recognized that employment decisions cannot be predicated on mere 'stereotyped' impressions about the characteristics of males or females," and that " $[\mathrm{m}] \mathrm{yths}$ and purely habitual assumptions about a woman's inability to perform certain kinds of work are no longer acceptable reasons for refusing to employ qualified individuals, or for paying them less").

41. See, e.g., Weinberger v. Wiesenfeld, 420 U.S. 636 (1975) (per curiam) (striking down a law granting Social Security benefits to wives of deceased breadwinning husbands but not to the husbands of deceased breadwinning wives in a challenge brought by a primary caregiving father).

42. See, e.g., Phillips v. Martin Marietta Corp., 400 U.S. 542 (1971) (holding employer's refusal to hire women, but not men, with school-age children to be unlawful sex discrimination in a challenge brought by a working mother).

43. See, e.g., Thorne v. City of El Segundo, 726 F.2d 459, 465 (9th Cir. 1983) (finding unlawful sex discrimination when an employer declined to hire a female police officer because of the "stereotyped view of the physical abilities of women").

44. See Cohen, supra note 21 , at 79-81.

45. See id. at 61-65.

46. See id. at 76-79.

47. See id. at 81-83.

48. See supra note 21.

49. See, e.g., Nguyen v. Immigr. \& Naturalization Serv., 533 U.S. 53, 65 (2001) (permitting sex discriminatory citizenship rule because unwed citizen mothers are more likely "to develop a real, meaningful relationship" with a newborn because of the "event of birth," compared to unwed citizen fathers); Lehr v. Robertson, 463 U.S. 248, 260-62, 260 n.16 (1983) (permitting sex discriminatory parental rights rule because 
based rules should fail this bar. ${ }^{50}$ My goal here, however, is not to criticize where sex discrimination law draws the line between lawful reliance on sex and unlawful reliance on stereotypes, but to establish that the law does draw such a line.

Traditional gender nonconformity doctrine established this line by distinguishing between valid reliance on sex and invalid reliance on sex stereotypes. Under this traditional doctrine, it had long been unlawful to assume that men and women would conform their gender to the stereotypes of their sex. ${ }^{51}$ It wasn't until Price Waterhouse v. Hopkins, ${ }^{52}$ however, that the Supreme Court announced a rule making it unlawful to expect that men and women would conform their gender to the stereotypes of their sex..53 In that case, an accounting firm denied a promotion to a woman, Ann Hopkins, not because it assumed she would conform her gender to her sex (i.e., she would be feminine) and thus be unqualified for the job, but because she failed to conform her gender to her sex (i.e., she was masculine), and this made her unqualified for the job. As the Court explained it:

One partner described her as "macho" ... another suggested that she "overcompensated for being a woman" ... a third advised her to take "a course at charm school." ... But [this was] the coup de grace: in order to improve her chances for partnership,... Hopkins [was to advised that she] should "walk

while "[t]he mother carries and bears the child, [so] ... her parental relationship is clear," the father must "grasp[] [the] opportunity" to become a parent through postbirth actions (internal quotation marks omitted)); Rostker v. Goldberg, 453 U.S. 57, 72-83 (1981) (permitting rule requiring only men to register for the draft because women were excluded from combat); Jespersen v. Harrah's Operating Co., 444 F.3d 1104, 1108-13 (9th Cir. 2006) (en banc) (upholding termination of employee for failing to comply with sex discriminatory appearance code because it did not impose an undue burden on one sex or unduly rely on sex stereotypes).

50. See, e.g., David Fontana \& Naomi Schoenbaum, Unsexing Pregnancy, 119 COLUM. L. REV. 309 (2019) (arguing that some pregnancy regulations are unlawful sex classifications grounded in stereotypes rather than real sex differences).

51. See Yuracko, supra note 14, at 763 n.19; see also, e.g., Thorne v. City of El Segundo, 726 F.2d 459 (9th Cir. 1983); Weinberger v. Wiesenfeld, 420 U.S. 636 (1975) (per curiam).

52. 490 U.S. 228 (1989) (plurality opinion).

53. See Yuracko, supra note 14, at 763-64 (describing the distinction between stereotypes assuming and expecting behavior on the basis of sex); Case, supra note 14, at 37-41 (describing same and discussing the trajectory and typology of sex stereotyping cases). Lower courts had barred sex stereotypical expectations before Price Waterhouse. See Brief of Employment Discrimination Law Scholars as Amici Curiae in Support of the Employees, supra note 15, at 10 (collecting cases showing that "in the 1970s and 1980s, courts and the EEOC applied Title VII's anti-stereotyping principle to decide Title VII sex discrimination claims where the employer relied on sex stereotypes not only about what men or women could do ... but also what men or women should do" (citation omitted)). 
more femininely, talk more femininely, dress more femininely, wear makeup, have her hair styled, and wear jewelry." 54

The Court held that the ban on sex discrimination extends to expecting that an individual conform to the traditional gender performance of their sex: "we are beyond the day when an employer could evaluate employees by assuming or insisting that they matched the stereotype" - the gender performance-"associated with their group"-male or female. ${ }^{55}$ The Court explained that protection against an expectation of conformity with stereotypical gender expectations was necessary because otherwise opportunities would be needlessly limited by sex. ${ }^{56}$ It is useful to get granular about the application of the doctrine, to make clear its treatment of sex and gender. The first step in applying the Price Waterhouse gender nonconformity doctrine requires determining the plaintiff's sex, i.e., that Ann Hopkins is a woman. ${ }^{57}$

From this naturally flows the traditional "stereotype associated with [each sex]," that is, femininity with women and masculinity with men. ${ }^{58}$ The next step requires consideration of how the employer perceived the plaintiff's gender. In Price Waterhouse, the employer viewed Hopkins as "masculine."59 The third step of the doctrine requires comparing the expected gender performance based on the plaintiff's sex with her perceived gender performance: if the employer

54. Price Waterhouse, 490 U.S. at 235 (citations omitted).

55. Id. at 251. This doctrine has since been extended beyond employment discrimination law. See, e.g., Back v. Hastings on Hudson Union Free Sch. Dist., 365 F.3d 107, 119 (2d Cir. 2004) (applying doctrine to a sex discrimination claim under the Equal Protection doctrine); Schwenk v. Hartford, 204 F.3d 1187, 1202 (9th Cir. 2000) (applying doctrine to a sex discrimination claim under the Gender Motivated Violence Act).

56. "An employer who objects to aggressiveness in women but whose positions require this trait places women in an intolerable and impermissible catch 22: out of a job if they behave aggressively and out of a job if they do not." Price Waterhouse, 490 U.S. at 251. The converse could be said for men: an employer who objects to sensitivity in men but whose positions require this trait places men in a similar catch-22: out of a job if they behave sensitively and out of a job if they do not.

57. I borrow here from Elizabeth M. Glazer \& Zachary A. Kramer, Transitional Discrimination, 18 TEMP. POL. \& C.R. L. REV. 651, 665 (2009), which discusses how "[t]he gender-stereotyping theory unfolds in three steps," although I differ with Glazer and Kramer in some respects. They view the doctrine as requiring consideration of whether the plaintiff's "anchor gender," which they define as "the gender commonly associated with a person's sex," matches the plaintiff's "expressive gender," which they define as "the plaintiff's particular gender expression," whereas I focus on how the sex stereotyping doctrine maps on to the traditional distinction between sex and gender.

58. Id. at 656 .

59. Price Waterhouse, 490 U.S. at 235. 
acted because these do not "match," the employer has engaged in unlawful sex stereotyping.

Note that the doctrine is premised on the idea of sex existing separate and apart from gender. So while legal scholars have made a case for viewing not only gender but sex as culturally constructed, 60 sex discrimination law rejects this view. ${ }^{61}$ In this way, the doctrine tracks the conventional separation of sex as "bio-physical aspects of personhood" and gender as "social constructions [such as] 'masculine' and 'feminine."' 62 While the precise biological source of sex has never been settled, sex has long been thought of as something based in the bodywhether chromosomes, hormones, physiology, or anatomy-whereas gender is socially layered on top. ${ }^{63}$ In other words, sex is who you are; gender is what you do. ${ }^{64}$ Under this view, sex might be fixed, but gender need not be. 65 So even while sex discrimination law operates to

60. See Franke, supra note 14, at 2 (critiquing sex discrimination law for "uncritically accept[ing] the validity of biological sexual differences," thereby "reify[ing] as foundational fact that which is really an effect of normative gender ideology"). See generally JUDITH BUTLER, GENDER TROUBLE: FEMINISM AND THE SUBVERSION OF IDENTITY (1990) (questioning as a societal construct the distinction between gender and sex); JUDITH BUTLER, BODIES THAT MATTER: ON THE DISCURSIVE LIMITS OF "SEX" 14 (1993) (same). I recognize this critique, but in this Article, I take sex discrimination law and the sex/gender distinction embedded within it as given and assess how the application of this law has failed in the context of transgender discrimination due to unnecessary confusion about sex and gender.

61. See, e.g., Nguyen v. Immigr. \& Naturalization Serv., 533 U.S. 53, 68 (2001) (holding that "biological differences" between men and women are not "gender-based stereotypes").

62. Francisco Valdes, Queers, Sissies, Dykes, and Tomboys: Deconstructing the Conflation of "Sex," "Gender," and "Sexual Orientation" in Euro-American Law and Society, 83 CALIF. L. REV. 1, 20-22 (1995); Case, supra note 14, at 10-11 (explaining that "[a]s most feminist theorists use the terminology, 'sex' refers to the anatomical and physiological distinctions between men and women; 'gender,' by contrast, is used to refer to the cultural overlay on those anatomical and physiological distinctions," so "[w]hile it is a sex distinction that men can grow beards and women typically cannot, it is a gender distinction that women wear dresses in this society and men typically do not").

63. See Ulane v. E. Airlines, Inc., 742 F.2d 1081, 1083 n.6 (7th Cir. 1984) (noting that "sex is defined by chromosomes, internal and external genitalia, hormones, and gonads"); Schwenk v. Hartford, 204 F.3d 1187, 1202 (9th Cir. 2000) (explaining that "sex" means "an individual's distinguishing biological or anatomical characteristics, whereas the term 'gender' refers to an individual's ... socially-constructed characteristics"); Smith v. City of Salem, 378 F.3d 566, 573 (6th Cir. 2004) (defining "sex" as "referring to an individual's anatomical and biological characteristics" and "gender" as "referring to socially-constructed norms associated with a person's sex").

64. See Case, supra note 14, at 12 (explaining that "gender is for adjectives," like "aggressive" or "strong," and "sex is for nouns," like man and woman).

65. See, e.g., Brief for Appellant at*15, Reed v. Reed, No. 70-4, 1971 WL 133596 (then-attorney Ruth Bader Ginsburg among others arguing that the state should not 
free men to act in feminine ways and women to act in masculine ways, it is at the same time premised in distinguishing between biological males and females.

\section{TRANSGENDER DISCRIMINATION AS GENDER NONCONFORMITY DISCRIMINATION}

This Part traces the transformation in judicial treatment of claims of sex discrimination brought by transgender plaintiffs. Courts initially rejected these claims because discrimination against someone who sought to change her sex designated at birth was not considered discrimination on the basis of sex. After the Price Waterhouse decision, courts reframed these claims as claims for gender nonconformity in the mold of plaintiffs like Hopkins. While this sometimes provided relief, it did so by reconceiving transgender status as premised in changing one's gender rather than changing one's designated sex. Over time, this conception has only intensified, with courts treating transgender plaintiffs as per se gender nonconformers, even suggesting that transgender persons are more nonconforming than traditional gender nonconformers.

\section{A. Nonrecognition: Transgender Status as a Matter of SeX}

In the 1970s and 80s, when courts first confronted sex discrimination claims by transgender plaintiffs, they consistently rejected these claims because transgender status fell outside the traditional definition of "sex."66 Many of these cases originated under Title VII.

presume that women are less qualified than men to serve as estate administrators because doing so discriminates on the basis of "congenital and unalterable biological traits of birth over which the individual has no control and for which he or she should not be penalized"); Frontiero v. Richardson, 411 U.S. 677, 682, 686 (1973) (applying heightened scrutiny to sex classifications in part because "sex ... is an immutable characteristic determined solely by the accident of birth" even though "the sex characteristic frequently bears no relation to ability to perform or contribute to society").

66. See, e.g., Ulane, 742 F.2d at 1086 (reversing district court's judgment that a transgender plaintiff suffered sex discrimination as a result of transgender status because the term "sex" should be given "its common and traditional interpretation"); Holloway v. Arthur Andersen \& Co., 566 F.2d 659, 661-63 (9th Cir. 1977) (affirming dismissal of sex discrimination claim by transgender plaintiff because discrimination on the basis of "initiating the process of sex transformation" is not discrimination on the basis of sex); Dobre v. Nat'l R.R. Passenger Corp., 850 F. Supp. 284, 286 (E.D. Pa. 1993) (dismissing sex discrimination claim raised by transgender plaintiff because the bar on sex discrimination does not "prohibit an employer from discriminating against a male because he wants to become a female"); Terry v. Equal Emp. Opportunity Comm'n, No. 80-C-408, 1980 WL 334, at *2 (E.D. Wis. Dec. 10, 1980) (dismissing sex discrimination complaint after employer refused to hire a transgender plaintiff because "the condition of being transsexual is not protected" under Title VII); Powell v. 
Courts reasoned that the statutory use of the term "sex" 67 refers to "an individual's distinguishing biological or anatomical characteristics." 68 Under this view, sex discrimination occurs when a person is treated differently "because he is a man or because he is a woman," that is, because of a "biological fact" of sex identity. ${ }^{69}$ Being transgender was not seen to qualify.

For example, in Ulane v. Eastern Airlines, the transgender plaintiff claimed to have been "fired by Eastern Airlines for no reason other than the fact that she ceased being a male and became a female."70 The court considered whether she had been discriminated against on the basis of sex because she was transgender or because she was female. ${ }^{71}$ It rejected the first theory because the statutory term "sex" should be given its "ordinary, common meaning" 72 and "its ... traditional

Read's, Inc., 436 F. Supp. 369, 371 (D. Md. 1977) (dismissing case of transgender plaintiff alleging sex discrimination, explaining that " $\mathrm{t}]$ he gravamen of the Complaint is discrimination against a transsexual and that is precisely what is not reached by Title VII" because it would be "inconsistent with the plain meaning of the words"); Grossman v. Bernards Twp. Bd. of Educ., No. 74-1904, 1975 WL 302, at *4, (D.N.J. Sept. 10, 1975), aff'd mem., 538 F.2d 319 (3d Cir. 1976) (dismissing sex discrimination claim brought by transgender plaintiff because she was discharged due to transgender status, and the term "sex" should be given "its plain meaning," which excludes transgender status); Voyles v. Ralph K. Davies Med. Ctr., 403 F. Supp. 456 (N.D. Cal. 1975), aff'd mem., 570 F.2d 354 (9th Cir. 1978) (dismissing claim of sex discrimination by plaintiff who told her employer that she "intended to undergo sex conversion surgery" because discrimination based on transgender status does not run afoul of Title VII). Scholars have criticized these decisions as incorrectly interpreting or ignoring the statutory text. See generally Cary Franklin, Inventing the "Traditional Concept" of Sex Discrimination, 125 HARV. L. REV. 1307 (2012) (arguing that the "traditional concept" of sex discrimination that courts relied on is based in normative judgments rather than the historical record); Jessica A. Clarke, How the First Forty Years of Circuit Precedent Got Title VII's Sex Discrimination Provision Wrong, 98 TEX. L. REv. ONLINE 83 (2019) (arguing that these decisions were based in judges' understanding of LGBTQ identities as pathological rather than the statutory text).

67. 42 U.S.C. § 2000e-2 (banning employers from "discriminat[ing] . . because of ... sex," among other protected grounds).

68. Dobre, 850 F. Supp. at 286; see also Holloway, 566 F.2d at 662-63 (agreeing with the view that "the term sex should be given the traditional definition based on anatomical characteristics").

69. Terry, 1980 WL 334 , at *3 (rejecting transgender discrimination claim because plaintiff "is not being refused employment because he is a man or because he is a woman"); Ulane, 742 F.2d at 1087; see also Holloway, 566 F.2d at 663 (rejecting transgender discrimination claim because "[ $t$ ] he manifest purpose of Title VII's prohibition against sex discrimination in employment is to ensure that men and women are treated equally").

70. Ulane, 742 F.2d at 1082 (internal quotation marks omitted).

71. Id. at 1087.

72. Id. at 1085 . 
interpretation,"73 neither of which encompasses discrimination against "a person born with a male body who believes himself to be female" or "discrimination based on ... discontent with the sex into which they were born."74 It rejected the second theory because, "[e]ven if we accept the district judge's holding that Ulane is female... [i]t is clear from the evidence that if Eastern did discriminate against Ulane, it was not because she is female, but because Ulane is a transsexual."75

In rejecting the notion that discrimination on the basis of transgender status was discrimination on the basis of sex, courts did so in a way that treated being transgender as about changing sex, not gender. These courts referred to the plaintiffs who came before them as "transsexuals," 76 a term they used to describe "a physiologically normal person [who] ... experiences discomfort or discontent about nature's choice of his or her particular sex and prefers to be the other sex." 77 And these decisions recognized that transgender plaintiffs subjectively "intended to change sex."78 Even the use of the term "transsexual" suggests changing sex.

Perhaps most importantly, these decisions recognized that transgender persons could change their designated sex. As in Ulane, in several of these cases, the transgender plaintiffs who were designated male at birth but identified as female alleged sex discrimination on the

73. Id. at 1086 .

74. Id. at 1085 .

75. Id. at 1087.

76. See id. at 1082; Sommers v. Budget Mktg., 667 F.2d 748, 748 n.2 (8th Cir. 1982) (discussing "transsexuality" of plaintiff); Kirkpatrick v. Seligman \& Latz, Inc., 636 F.2d 1047, 1048 (5th Cir. Unit B 1981) ("This is an appeal by a transsexual plaintiff ...."); Holloway v. Arthur Andersen \& Co., 566 F.2d 659, 661 (9th Cir. 1977) (noting that the plaintiff is "a transsexual"); Dobre v. Nat'l R.R. Passenger Corp., 850 F. Supp. 284, 285 (E.D. Pa. 1993) (referring to the plaintiff as "a transsexual"); Powell v. Read's, Inc., 436 F. Supp. 369, 370 (D. Md. 1977) (describing plaintiff as "a transsexual"); Voyles v. Ralph K. Davies Med. Ctr., 403 F. Supp. 456, 457 (N.D. Cal. 1975), aff'd mem., 570 F.2d 354 (9th Cir. 1978) (acknowledging plaintiff's "transsexuality").

77. Ulane, 742 F.2d at 1083 n.3 (emphasis added); see also Sommers, 667 F.2d at 748 n.2 ("A transsexual has been described as an individual who is mentally of one sex but physically of the other .... or as one born with the anatomical genitalia of one sex but whose self-identity is of the other sex.").

78. Voyles, 403 F. Supp. at 456 (indicating that plaintiff "intended to change sex"); see also Dobre, $850 \mathrm{~F}$. Supp. at 286 (describing the case as addressing the question of whether Title VII prohibits discrimination "against a male because he wants to become a female"); Terry v. Equal Emp. Opportunity Comm'n., No. 80-C-408, 1980 WL 334, at $* 1, * 3$ (E.D. Wis. Dec. 10, 1980) (describing plaintiff as "a physical male who wants to become female"). 
basis of being female ${ }^{79}$ in addition to or instead of on the basis of transgender status. ${ }^{80}$ These courts were put in a position to consider the sex of the plaintiff. Some courts punted on the question, assuming arguendo that the plaintiffs were female. ${ }^{81}$ Other courts adopted an anatomical view of sex, deciding that the plaintiffs were male, but only because they had yet to undergo surgery to change their anatomy. ${ }^{82}$ In so doing, they accepted the principle that transgender persons could change their assigned sex under the right circumstances, suggesting that if the plaintiffs had undergone sex reassignment surgery,

79. The Ninth Circuit had explained early on that although discrimination on the basis of transgender status is not discrimination on the basis of sex, "transsexuals claiming discrimination because of their sex, male or female, would clearly state a cause of action under Title VII." Holloway, 566 F.2d at 664; see also Dobre, 850 F. Supp. at 287.

80. Ulane, 742 F.2d at 1087 (explaining that the trial judge "amended his findings to hold that Ulane is also female and has been discriminated against on this basis"); Sommers, 667 F.2d at 749 ("Sommers's amended complaint claimed she had been discriminated against because of her status as a female ...."); Kirkpatrick, 636 F.2d at 1048 (considering whether plaintiff had been discriminated against on the basis of sex because she was treated differently than female employees); Dobre, 850 F. Supp. at 287 (considering whether "the allegations in the complaint ... support a claim that the plaintiff was discriminated against as a female"); Grossman v. Bernards Twp. Bd. of Educ., No. 74-1904, 1975 WL 302, at*4 (D.N.J. Sept. 10, 1975), aff'd mem., 538 F.2d 319 (3d Cir. 1976) (considering whether plaintiff alleged any facts to support that she was terminated on the basis of being female).

81. Ulane, 742 F.2d at 1087 ("Even if we accept the district judge's holding that Ulane is female, he made no factual findings necessary to support his conclusion that Eastern discriminated against her on this basis."); Dobre, 850 F. Supp. at 287 (explaining that " $[\mathrm{t}]$ he Court need not determine the plaintiff's sex during her employment with AMTRAK, as a matter of law, to resolve the present motion," because it would "assume for purposes of the present motion that the plaintiff was a female during her employment with AMTRAK," but nonetheless rejecting the claim because "the allegations in the complaint do not support a claim that the plaintiff was discriminated against as a female"); Grossman, 1975 WL 302, at *4 (explaining that "[t]he Court finds it unnecessary and, indeed, has no desire, to engage in the resolution of a dispute as to the plaintiff's present sex," and "[r]ather, we assume for the purpose of this action that the plaintiff is a member of the female gender," but rejecting the discrimination claim for lack of allegations to support it). Even courts' willingness to assume arguendo that these plaintiffs were female shows that the notion of transgender persons changing their sex was not off the wall.

82. See Sommers, 667 F.2d at 749 (acknowledging medical dispute as to the sex of a person who is anatomically one sex but psychologically feels another, concluding that "[p]laintiff, for the purposes of Title VII, is male because she is an anatomical male"); Kirkpatrick, 636 F.2d at 1049 (treating a transgender plaintiff designated male at birth who had yet to undergo the "sex reassignment process" as a male); $c f$. Powell v. Read's, Inc., 436 F. Supp. 369, 370 (D. Md. 1977) (explaining that the plaintiff planned to undergo a "sex change operation"); Grossman, 1975 WL 302, at *2 (quoting earlier decision maker that plaintiff "knowingly and voluntarily underwent a sex-reassignment from male to female"). 
they would be female.83 So even in rejecting sex discrimination protection for transgender persons, these early decisions appreciated that transgender persons were changing their sex, not their gender.

\section{B. Recognition: A Shift from SeX to Gender}

Starting in the early 2000s, courts began applying the gender nonconformity doctrine to cases of sex discrimination brought by transgender plaintiffs. ${ }^{84}$ One of the earliest Court of Appeals cases to reach this conclusion was Smith v. City of Salem, Ohio. ${ }^{85}$ There, the plaintiff, whom the Sixth Circuit described as a "transsexual" who is "biologically and by birth a male," had been diagnosed with Gender Identity Disorder (GID). 86 Consistent with treatment for GID, Smith

83. See Sommers, 667 F.2d at 749 (indicating that if plaintiff had "sexual conversion surgery" performed, she would be female, and noting that "the district court ordered Sommers to submit an amended complaint to indicate ... whether she had in fact successfully undergone sexual conversion surgery," as well as noting plaintiff's answer in the negative, suggesting that plaintiff's sex turned on this); Kirkpatrick, 636 F.2d at $1048 \mathrm{n} .1$ (stating that a transgender plaintiff designated male at birth who had undergone the "sex reassignment process" was "entitled ... to identify herself as a female"); see also Terry, 1980 WL 334, at *3 (stating that a transgender plaintiff designated male at birth who had yet to undergo gender-confirming surgery "is still a male" and "at this point he only desires to be female," indicating that after surgery she would in fact be female (emphasis added)); Powell, 436 F. Supp. at 370 (explaining that the transgender plaintiff designated male at birth who had yet to undergo gender-confirming surgery is "still legally a male," indicating that she would be female after surgery (emphasis added)). The outlier is the Seventh Circuit in Ulane, which was still uncertain of the plaintiff's sex even after gender-confirming surgery. See Ulane, 742 F.2d at 1087 (stating that "[a]fter the surgery, hormones, appearance changes, and a new Illinois birth certificate and FAA pilot's certificate, it may be that society, as the trial judge found, considers Ulane to be female" but nonetheless describing the post-operative plaintiff as "a biological male who takes female hormones, cross-dresses, and has surgically altered parts of her body to make it appear to be female"); id. at $1083 \mathrm{n} .6$ (recognizing disagreement in medical community between those who "conclude that hormone treatments and sex reassignment surgery ... cannot change the individual's innate sex" and those who "conclude that post-operative male-to-female transsexuals do in fact qualify as females").

84. Often cited as the first case to do so is Rosa v. Park West Bank \& Trust Co., 214 F.3d 213 (1st Cir. 2000), which cited Price Waterhouse and concluded that a plaintiff alleging that he was a male who was denied a loan application because he was dressed in traditionally female attire stated a claim of sex discrimination under the Equal Credit Opportunity Act. I don't include this case because there was no claim that the plaintiff there was transgender rather than a cross-dresser or simply a man who was wearing women's clothing.

85. Smith v. City of Salem, 378 F.3d 566, 568 (6th Cir. 2004).

86. Id. In 2013, the American Psychiatric Association released the fifth edition of its Diagnostic and Statistical Manual of Mental Disorders (DSM-5), which replaced "gender identity disorder" with "gender dysphoria." AM. PSYCHIATRIC ASS'N, DiAGNOSTIC and Statistical Manual of Mental Disorders 452, 454 (5th ed. 2013). Gender 
adopted "a more feminine appearance on a full-time basis." 87 Soon thereafter, Smith's coworkers began commenting that Smith's appearance and mannerisms were not "masculine enough." 88 Smith claimed that the employer was discriminating due to gender non-conforming conduct. 89

The court concluded that Smith pleaded a claim of sex discrimination based on discrimination due to his failure to "conform with his employers' and co-workers' sex stereotypes of how a man should look and behave." 90 The Sixth Circuit explained how Price Waterhouse had changed the landscape for transgender plaintiffs:

After Price Waterhouse, an employer who discriminates against women because, for instance, they do not wear dresses or makeup, is engaging in sex discrimination because the discrimination would not occur but for the victim's sex. It follows that employers who discriminate against men because they do wear dresses and makeup, or otherwise act femininely, are also engaging in sex discrimination, because the discrimination would not occur but for the victim's sex.91

The court not only rejected pre-Price Waterhouse precedents denying sex discrimination claims by transgender persons, but also post-Price Waterhouse precedents that had denied transgender plaintiffs' sex discrimination claims by distinguishing between discrimination on the basis of gender nonconformity, which is prohibited, and discrimination on the basis of transgender status, which is not. ${ }^{92}$ Smith explained that no such distinction could be drawn: "irrespective of the cause of [gender non-conforming] behavior, a label, such as 'transsexual,' is not fatal to a sex discrimination claim where the victim has suffered discrimination because of his or her gender non-conformity."93 To be protected, transgender status had to stop being recognized as a distinct phenomenon and had to start being recognized as a species of gender nonconformity.

In extending the gender nonconformity doctrine to transgender plaintiffs, courts apply the Price Waterhouse three-step. ${ }^{94}$ First, courts

dysphoria defines the "clinically significant distress" associated with the mismatch between identity and sex assigned at birth as a psychological disorder, whereas gender identity disorder defined the mismatch itself to be the disorder. Id. at 459 .

87. Smith, 378 F.3d at 568 (internal quotation marks omitted).

88. Id.

89. Id.

90. Id. at 572 .

91. Id. at 574 .

92. Id. (citing, for example, Dillon v. Frank, No. 90-2290, 1992 WL 5436 (6th Cir. Jan. 15, 1992)).

93. Id. at 575 .

94. See supra notes 59-60 and accompanying text. 
must identify the plaintiff's sex, which was "male" in Smith. ${ }^{95}$ And courts have adopted a particular notion of sex in so doing, which is sex assigned at birth. ${ }^{96}$ In Smith, for example, the court says that the plaintiff "asserts that he is a male with Gender Identity Disorder." 97 However, Smith's complaint states that Smith was "designated as male at birth," not that Smith is in fact male. ${ }^{98}$ The court's failure to appreciate that Smith's identity turned precisely on the fact that she is a woman rather than a man demonstrates how courts have failed to recognize transgender persons' identities under the gender nonconformity doctrine.

Next, courts compare the gender performance of these plaintiffs, which Smith identified as "feminine,"99 with their expected gender performance, which was masculine. Because these did not "match[],"100 the courts analogized these cases to Price Waterhouse and held that they should be resolved the same way. ${ }^{101}$ In other words,

95. Smith, 378 F.3d at 568, 574 (describing plaintiff as "male" and explaining that Price Waterhouse applies to "men" who "do wear dresses and makeup, or otherwise act femininely").

96. See, e.g., id. at 568 (describing plaintiff as "biologically and by birth a male"); Schwenk v. Hartford, 204 F.3d 1187, 1201 (9th Cir. 2000) (describing "[m]ale-to-female transgenders" as "anatomical males"); Glenn v. Brumby, 663 F.3d 1312, 1314 (11th Cir. 2011) (stating that the transgender plaintiff "was born a biological male"). Sex assigned at birth, sometimes called natal sex, is based on a newborn's anatomy and is often viewed as legally fixed once determined. See Franke, supra note 14, at 52-58 (collecting cases to this effect). In cases where transgender plaintiffs have not had gender confirming surgery, sex assigned at birth and anatomical sex will coincide. But see Case, supra note 14, at 15 n.35 (discussing intersexuality, where reproductive and sexual anatomy may not fit typical definitions of male or female). Decisions addressing transgender discrimination before Price Waterhouse largely suggested that a surgical change to anatomy would suffice for a legal sex change. See supra note 83 and accompanying text. The post-Price Waterhouse cases under study here largely involve transgender plaintiffs who had not (yet) undergone surgery, so it has not been tested whether courts would treat transgender persons who had done so differently. For a post-Price Waterhouse case suggesting that surgery is sufficient to change biological sex for Title VII purposes, see Tronetti v. TLC HealthNet Lakeshore Hosp., No. 03-cv0375E(SC), 2003 WL 22757935, at *1 (W.D.N.Y. Sept. 26, 2003), which described a plaintiff "who, prior to sexual reassignment surgery, was a biological male transsexual" and "had been a male at all times relevant to the Complaint-i.e., before undergoing surgery" (emphasis added).

97. 378 F.3d at 570 .

98. Complaint at 5, Smith v. City of Salem, No. 4:02CV1405 (N.D. Ohio July 19, 2002).

99. Smith, 378 F.3d at 568 (describing plaintiff's appearance as "feminine"); Schwenk, 204 F.3d at 1193, 1202 (same).

100. Price Waterhouse v. Hopkins, 490 U.S. 228, 251 (1989).

101. Smith, 378 F.3d at 572 ("Having alleged that his failure to conform to sex stereotypes concerning how a man should look and behave was the driving force behind 
the transgender plaintiff designated male at birth is an effeminate man discriminated against for failing to conform gender to sex.

In applying Price Waterhouse to transgender plaintiffs, courts conceive of transgender persons as they did Ann Hopkins, retaining the sex they were assigned at birth and changing their gender. ${ }^{102}$ The doctrine itself presumes a change of gender but not sex. If the transgender plaintiff who is designated male at birth and who adopts a feminine gender performance were in fact a female (or if the transgender plaintiff who is designated female at birth and who adopts a masculine gender performance were in fact a male), there would be no gender nonconformity.

As courts have explained it, protecting transgender plaintiffs as gender nonconformers was a natural and inevitable outgrowth of sex discrimination law's shift in the treatment of sex and gender. ${ }^{103}$ As Smith states, "[b]y holding that Title VII protected a woman who failed to conform to social expectations concerning how a woman should look and behave, the Supreme Court established that Title VII's reference to 'sex' encompasses both the biological differences between men and women, and gender discrimination, that is, discrimination based on a failure to conform to stereotypical gender norms." $104 \mathrm{~A}$ Ninth Circuit decision went even further, stating that "[a]s used in Title VII, the term 'sex' encompasses both sex, i.e., the biological differences between men and women, and gender," and that "for purposes of [Title VII], the terms 'sex' and 'gender' have become interchangeable." 105

This description of how sex discrimination protection came to be extended to transgender plaintiffs ignores how it was a change not

Defendants' actions, Smith has sufficiently pleaded claims of sex stereotyping and gender discrimination."); Schwenk, 204 F.3d at 1202 ("Thus, the evidence offered by Schwenk tends to show that [the defendant]'s actions were motivated, at least in part, by Schwenk's gender-in this case, by her assumption of a feminine rather than a typically masculine appearance or demeanor.").

102. In Smith, for example, the Sixth Circuit says that "[d]iscrimination against a plaintiff who is a transsexual-and therefore fails to act and/or identify with his or her gender-is no different from the discrimination directed against Ann Hopkins in Price Waterhouse, who, in sex-stereotypical terms, did not act like a woman." 378 F.3d at 575. Although the court uses the term "gender," it must mean sex.

103. Despite courts' depiction of it as such, there is a strong case to be made that Price Waterhouse did not represent a significant shift in sex discrimination law. As Professor Mary Anne Case explained, the decision can be understood in simple terms of "disparate treatment" on the basis of sex: if Ann Hopkins had been a man, she would not have been subject to expectations of femininity. See Case, supra note 14, at 4 .

104. Smith, 378 F.3d at 573 (citing Price Waterhouse, 490 U.S. at 251).

105. Schwenk, 204 F.3d at 1202. 
just in precedent, but in courts' understanding of being transgender, that led to this doctrinal extension. Courts began treating transgender persons as persons who changed their gender rather than persons who changed their sex. ${ }^{106}$ Over twenty years ago, Professor Mary Anne C. Case noted how sex discrimination law had begun to speak of all matters of sex in terms of gender. ${ }^{107}$ As courts have increasingly treated transgender discrimination as a matter of gender rather than sex, this tendency to treat all sex discrimination as a matter of gender has only grown and continued to cause harm.

Smith obscures this shift in its discussion of the earlier precedents rejecting transgender plaintiffs' sex discrimination claims. As Smith describes it, these claims were rejected "because [these plaintiffs] were considered victims of 'gender' rather than 'sex' discrimination." 108 But, as explained above, these courts understood transgender status to be about changing sex rather than changing gender. ${ }^{109}$ Smith thus downplays how a critical aspect of folding transgender plaintiffs into the protection of sex discrimination law was this new understanding of being transgender itself.

106. Compare supra notes 76-83 and accompanying text (collecting cases treating transgender status as a matter of changing sex), with supra notes 94-102 and accompanying text (collecting cases treating transgender status as a matter of changing gender).

107. See Case, supra note 14 , at 10 (discussing this shift and attributing it to thenadvocate Ruth Bader Ginsburg).

108. Smith, 378 F.3d at 573.

109. See, e.g., Ulane v. E. Airlines, Inc., 742 F.2d 1081, 1085 (7th Cir. 1984) (describing transgender status as involving "a person born with a male body who believes himself to be female" or a person who has "discontent with the sex into which they were born"); supra notes 70-75 and accompanying text. 
Extending the gender nonconformity doctrine to transgender plaintiffs led to a sea change in the treatment of their sex discrimination claims. ${ }^{110}$ Both courts of appeals ${ }^{111}$ and district courts 112

110. Macy v. Holder, No. 0120120821, 2012 WL 1435995, at *7 (E.E.O.C. Apr. 20, 2012) ("[S]ince Price Waterhouse, courts have widely recognized the availability of the sex stereotyping theory as a valid method of establishing discrimination 'on the basis of sex' in scenarios involving individuals who act or appear in gender-nonconforming ways.").

111. Glenn v. Brumby, 663 F.3d 1312, 1317 (11th Cir. 2011) (in a claim alleging sex discrimination under the Equal Protection Clause, applying the sex stereotyping doctrine to hold that "discrimination against a transgender individual because of her gender-nonconformity is sex discrimination"); Chavez v. Credit Nation Auto Sales, LLC, 641 F. App'x 883, 884 (11th Cir. 2016) (reversing summary judgment for the employer on a transgender plaintiff's sex discrimination claim based on her transgender status because "[s]ex discrimination includes discrimination against a transgender person for gender nonconformity"); Barnes v. City of Cincinnati, 401 F.3d 729, 737 (6th Cir. 2005) (holding that the "failure to conform to sex stereotypes concerning how a man should look and behave" by a transgender plaintiff designated male at birth is sufficient to state a sex discrimination claim).

112. See Doe v. Arizona, No. CV-15-02399, 2016 WL 1089743, at*2 (D. Ariz. Mar. 21,2016 ) (denying the employer's motion to dismiss on "transgender male" plaintiff's claim of sex discrimination, recognizing that "discrimination against a transgender individual because of her gender-nonconformity is sex discrimination" (internal quotation marks omitted)); Fabian v. Hosp. of Cent. Conn., 172 F. Supp. 3d 509, 527-28 (D. Conn. 2016) (holding that "in light of ... Price Waterhouse's acknowledgement that gender-stereotyping discrimination is discrimination 'because of sex,'” concluding that discrimination on the basis of transgender identity is cognizable under Title VII and allowing a claim supported by evidence of such discrimination to survive summary judgment); United States v. Se. Okla. State Univ., No. CIV-15-324-C, 2015 WL 4606079, at *2 (W.D. Okla. July 10, 2015) (in denying motion to dismiss transgender plaintiff's claim of sex discrimination under Title VII, recognizing that although under Tenth Circuit precedent "transsexuals may not claim protection under Title VII from discrimination based solely on their status as a transsexual," the label "transsexual' is not fatal to a sex discrimination claim where the victim has suffered discrimination because of his or her gender non-conformity" and finding that plaintiff's allegations met this standard (internal quotation marks omitted)); Parris v. Keystone Foods, LLC, 959 F. Supp. 2d 1291, 1303 (N.D. Ala. 2013) (acknowledging that, under the principle that "[d] iscrimination against a transgender individual because of her gender-nonconformity is sex discrimination," Title VII covers "transgender" plaintiff's claim that her employer discharged her for "fail[ing] to adhere to conventional gender roles and stereotypes," but granting summary judgment to employer because plaintiff had failed to present evidence to establish discrimination in this manner (internal quotation marks omitted)); Lopez v. River Oaks Imaging \& Diagnostic Grp., Inc., 542 F. Supp. 2d 653, 660 (S.D. Tex. 2008) (explaining that "Title VII is violated when an employer discriminates against any employee, transsexual or not, because he or she has failed to act or appear sufficiently masculine or feminine enough for an employer" and that the plaintiff has "developed facts in support of a claim that River Oaks discriminated against her, not because she is transgendered, but because she failed to comport with [the employer's] notions of how a male should look"); Lie v. Sky Publ'g Corp., No. 013117, 2002 WL 31492397, at*5 (Mass. Super. Ct. Oct. 7, 2002) (holding that a transgender plaintiff 
adopted the logic of these cases, applying Price Waterhouse to decide whether transgender discrimination is sex discrimination, and decided in the affirmative, at least in the subset of cases that, like Hopkins and Smith, claimed discrimination on the basis of gender performance. Scholars too praised the application of the gender nonconformity theory to cases of discrimination against transgender plaintiffs. ${ }^{113}$ The new law of gender nonconformity was now the law of the land.

\section{The Intensification of Transgender Status as Gender NONCONFORMITY}

From this near universal acceptance, the treatment of transgender persons as gender nonconformers only intensified. First, courts came to treat transgender persons as per se gender nonconformers. The cases described in the last Part consider discrimination against a transgender person to be unlawful sex discrimination on an "as applied" basis, that is, when the discrimination is based in the particular plaintiff's gender nonconformity. 114 Some courts and scholars have gone further, adopting what I call the "per se" approach-the view that transgender persons are "inherently" gender non-conforming, and thus that being transgender is, by definition, gender nonconformity to sex. 115

designated male at birth had set forth a prima facie case of sex discrimination because the defendant's conduct-requesting that the plaintiff wear only traditionally male attire at work and subsequently firing the plaintiff upon her refusal- "was based on stereotyped notions of 'appropriate' male and female behavior in the same manner as the conduct of the defendant in Price Waterhouse"); Mitchell v. Axcan Scandipharm, Inc., No. Civ. A. 05-243, 2006 WL 456173, at*2 (W.D. Pa. Feb. 17, 2006) (denying motion to dismiss claim of sex discrimination by transgender plaintiff designated male at birth who was terminated after presenting at work as a female because the complaint "included facts showing that his failure to conform to sex stereotypes of how a man should look and behave was the catalyst behind defendant's actions"); Tronetti v. TLC HealthNet Lakeshore Hosp., No. 03-cv-0375E(SC), 2003 WL 22757935, at*4 (W.D.N.Y. Sept. 26,2003 ) (deciding that transgender plaintiff's "Title VII claim-based on the alleged discrimination for failing to 'act like a man'-is actionable" under Price Waterhouse's holding that "[d]iscrimination because one fails to act in the way expected of a man or a woman is forbidden under Title VII" (internal quotation marks omitted)).

113. See, e.g., Franke, supra note 14, at 96 (asserting that "there is no principled way to distinguish [transgender discrimination cases] from Price Waterhouse"); Grenfell, supra note 14, at 67 (noting that the sex stereotyping approach "has recently become the trend in trans litigation and commentary," and arguing that "[t]his line of reasoning is apposite to transgender plaintiffs because, by definition, their appearance, mannerisms and behavior, which perform their psychological gender, do not match the social stereotypes associated with their birth sex").

114. See sources cited supra notes 97-99.

115. E.g., Harris II, 884 F.3d 560, 576 (6th Cir. 2018); see also Glenn, 663 F.3d at 1316 (explaining that "[a] person is defined as transgender precisely because of the 
The Sixth Circuit's decision in Stephens's case illustrates the per se approach. ${ }^{116}$ There, a transgender woman who was "born biologically male" alleged that she was discriminated against because she began to "represent herself ... as a female." 117 After restating its holding from Smith that "sex stereotyping based on a person's gender nonconforming behavior is impermissible discrimination," 118 it explained how discrimination on the basis of being transgender always involves discrimination on the basis of gender nonconformity. 119 "[D]iscrimination against transgender persons necessarily implicates Title VII's proscriptions against sex stereotyping," because a "transgender person is someone who fails to act and/or identify with his or her gender-i.e., someone who is inherently gender non-conforming." 120

Moreover, it has been suggested not only that transgender persons are gender nonconformers, but that they are more nonconforming than gender nonconformers of the past, like Hopkins. ${ }^{121}$ Under this

perception that his or her behavior transgresses gender stereotypes," and "[ $t$ ]here is thus a congruence between discriminating against transgender ... individuals and discrimination on the basis of gender-based behavioral norms"); Finkle v. Howard Cnty., 12 F. Supp. 3d 780, 788 (D. Md. 2014) (denying motion to dismiss or for summary judgment on a Title VII claim of sex discrimination based in plaintiff's "transsexual status" because "it would seem that any discrimination against transsexuals (as transsexuals) - individuals who, by definition, do not conform to gender stereotypes-is proscribed by Title VII's proscription of discrimination on the basis of sex as interpreted by Price Waterhouse"); Macy v. Holder, No. 0120120821, 2012 WL 1435995, at *9-11 (E.E.O.C. Apr. 20, 2012) (concluding that intentional discrimination against a transgender person "is, by definition, discrimination 'based on ... sex,"' because "[a] person is defined as transgender precisely because of the perception that his or her behavior transgresses gender stereotypes" (citations omitted)). Scholars too have advocated this view. See Grenfell, supra note 14, at 67 (praising the application of the sex stereotyping approach to transgender plaintiffs, "because, by definition, their appearance, mannerisms and behavior, which perform their psychological gender, do not match the social stereotypes associated with their birth sex"); Turner, supra note 14, at 563 ("The very acts that define transgender people as transgender are those that contradict stereotypes of gender-appropriate appearance and behavior.").

116. Harris II, 884 F.3d at 576.

117. Id. at 566 .

118. Id. at 572 (internal quotation marks omitted).

119. Id. at 577 ("We did not expressly hold in Smith that discrimination on the basis of transgender status is unlawful ... [but] we now directly hold: Title VII protects transgender persons because of their transgender or transitioning status, because transgender or transitioning status constitutes an inherently gender non-conforming trait.").

120. Id. at 576 (internal quotation marks omitted).

121. See Glenn v. Brumby, 663 F.3d 1312, 1318-19 (11th Cir. 2011) (cataloguing examples of protection for gender nonconformity, including "wearing jewelry that was considered too effeminate, carrying a serving tray too gracefully, or taking too active a role in child-rearing," and explaining that they extend to the "transgender individual" 
view, while plaintiffs like Hopkins are only partial gender nonconformers, because they "reject discrete aspects of their prescribed gender code while maintaining conformity with others," transgender plaintiffs are complete gender nonconformers who reject an entire "gender code."122 This perspective not only views transgender persons as gender nonconformers, but sets up transgender plaintiffs, rather than plaintiffs like Hopkins, as the paragon of gender nonconformity. Transgender persons have thus gone from questionable or marginal gender nonconformers to the paradigm case.

The intensification of transgender plaintiffs as gender nonconformers has brought a substantial shift in how transgender persons are treated under sex discrimination law. Being transgender was once seen as a distinct phenomenon from gender nonconformity, like being gay or lesbian, that would deny transgender persons protection under the gender nonconformity doctrine. ${ }^{123}$ Now, transgender plaintiffs are not only seen as gender nonconformers, but are often seen as per se gender nonconformers, without any other proof of gender nonconformity, and more gender nonconforming than their cisgender brothers and sisters. Courts have thus gone from excluding transgender plaintiffs from protection under the gender nonconformity doctrine to taking them to its center.

\section{THE FAILURES OF TREATING TRANSGENDER PERSONS AS GENDER NONCONFORMERS}

While transgender persons gained some sex discrimination protection as gender nonconformers, the doctrine has not protected them in all cases of sex discrimination. In cases where transgender plaintiffs seek the right to access sex-based classifications, the doctrine has often led to failure because these are not cases of discrimination due to gender nonconformity. And even in cases like Smith that address gender discrimination, protection under the doctrine comes at a steep cost: the doctrine both presumes and reinforces transgender plaintiffs' birth-designated sex-a view that is at odds with substantial medical and legal authority, as well as with what plaintiffs often claim to assert lawful access to sex-segregated spaces. Still further, wrongly lumping together transgender plaintiffs and gender nonconformers under the doctrine undermines protection for gender nonconformity.

because "[t]he nature of the discrimination ... may differ in degree but not in kind" (emphasis added)).

122. Yuracko, supra note 14 , at 794.

123. See supra notes $92-93$ and accompanying text. 
This Part begins by explaining how the gender nonconformity doctrine has led transgender plaintiffs to lose in cases that turn on sex classifications. It then sets forth how the doctrine does harm even in cases where transgender plaintiffs prevail. Finally, this Part details how the application of the gender nonconformity doctrine to transgender plaintiffs weakens the doctrine's protection for gender nonconformity.

\section{A. Compelling Losses}

Transgender sex discrimination cases can be divided into two types. One set of cases addresses transgender persons who claim sex discrimination because they are penalized for being too feminine or too masculine. These cases, with circumstances similar to Smith, recognize discrimination against transgender plaintiffs as a species of gender nonconformity discrimination along the lines of Price Waterhouse: a transgender person designated female at birth who has been penalized for being too masculine is analogized to Ann Hopkins, a woman who was penalized for being too masculine. I call these cases the gender performance cases. I return to the gender performance cases in the next Section.

Another set of cases addresses transgender persons who, like Aimee Stephens, claim sex discrimination after being denied access to sex classifications (e.g., bathrooms, dress codes) because they are believed to be the wrong sex to access the classification they seek. ${ }^{124}$ I call these cases the sex classification cases. As for these cases, applying the gender nonconformity doctrine and treating transgender status as a matter of gender rather than sex means that plaintiffs in these cases have often lost before they have even begun.

Sex classification cases are not gender nonconformity cases. Transgender plaintiffs in the sex classification cases are in a quite different posture than gender nonconforming plaintiffs like Hopkins. The hallmark of gender nonconforming plaintiffs of the past was that they challenged sex-based rules that either assumed or expected gender to

124. Harris II, 884 F.3d at 568-69; see also Etsitty v. Utah Transit Auth., 502 F.3d 1215, 1219 (10th Cir. 2007) (transgender employee designated male at birth seeking right to access female bathrooms); Kastl v. Maricopa Cnty. Comm. Coll. Dist., 325 F. App'x 492, 493-94 (9th Cir. 2009) (same); Complaint at*7, Daskalakis v. Forever 21, Inc., 2016 WL 4487747 (E.D.N.Y. Aug. 25, 2016) (No. 15-CV-1768), 2015 WL 1531240 (transgender employee designated male at birth seeking right to comply with female dress code); Creed v. Fam. Express Corp., No. 3:06-CV-465RM, 2009 WL 35237 (N.D. Ind. Jan. 5, 2009) (same). See supra note 18 on the factual basis for Stephens's termination. 
conform to sex.125 This was how they combatted sex stereotypes: by challenging rules that assumed or expected gender conformity. Hopkins challenged her employer's unwritten rule expecting women to be feminine and men to be masculine, 126 and other gender nonconformity plaintiffs have challenged formal sex discriminatory rules, including dress codes. 127

In sex-classification cases, by contrast, a transgender plaintiff designated male at birth seeks the right to use the women's rather than the men's bathroom or comply with the female rather than the male dress code. These plaintiffs are not challenging sex classifications; they are seeking access to them.128 The district court in Stephens's case thought it quite strange that a transgender plaintiff was seeking the right to comply with a stereotypically feminine dress code by relying on a doctrine aimed precisely at dismantling such stereotypes. It is worth quoting the court at length to appreciate the confusion that the gender nonconformity doctrine sows here:

The only reason that the EEOC can pursue a Title VII claim on behalf of Stephens in this case is under the theory that the Funeral Home discriminated against Stephens because Stephens failed to conform to the "masculine gender stereotypes that [the employer] expected" in terms of the clothing Stephens would wear at work. The EEOC asserts that Stephens has a "Title VII right not to be subject to gender stereotypes in the workplace." ... Yet the EEOC has not challenged the Funeral Home's sex-specific dress code[] that requires female employees to wear a skirt-suit and requires male employees to wear a suit with pants and a neck tie, in this action.... Rather than challenge the sex-specific dress code, the EEOC takes the position that Stephens has the right, under Title VII, to "dress as a woman" or wear "female clothing" while working at the Funeral Home.... That is, the EEOC wants Stephens to be permitted to dress in a stereotypical feminine manner (wearing a skirtsuit), in order to express Stephens's gender identity. ${ }^{129}$

The court makes quite plain the mismatch between the gender nonconformity doctrine and the right that transgender plaintiffs seek in sex classification cases. In light of this mismatch, it is no wonder that transgender plaintiffs have lost in sex classification cases under the gender nonconformity doctrine. ${ }^{130}$

125. See supra notes 31-32 and accompanying text.

126. See supra notes $40-43$ and accompanying text.

127. See, e.g., Jespersen v. Harrah's Operating Co., 444 F.3d 1104, 1106 (9th Cir. 2006) (en banc) (seeking relief for termination due to failure to comply with employer's female-only make-up requirement).

128. See sources cited supra note 111.

129. Harris I, 201 F. Supp. 3d 837, 861 (E.D. Mich. 2016) (citations omitted).

130. See Etsitty v. Utah Transit Auth., 502 F.3d 1215, 1219 (10th Cir. 2007) (denying claim of transgender employee designated male at birth seeking right to access female bathrooms); Kastl v. Maricopa Cnty. Comm. Coll. Dist., 325 F. App’x 492, 493-94 
The district court's objection also raises a more fundamental question about embracing protection against transgender discrimination within sex discrimination law: whether it fails to serve-or perhaps even undermines-that law's anti-stereotyping aims. Because transgender discrimination cases are analyzed under the gender nonconformity doctrine, but do not combat sex stereotypes by challenging sex classifications as other gender nonconformity cases, courts may assume that such cases do not serve the goals of sex discrimination law. We will see in the next Part how transgender plaintiffs in sex classification cases do fight sex stereotypes. ${ }^{131}$ Here, the point is how sex classification claims are an ill fit under the gender nonconformity doctrine.

There is another even simpler reason that transgender plaintiffs lose in sex classification cases under the gender nonconformity doctrine: there is no suggestion that transgender plaintiffs have been denied access to sex classifications based on the fact of gender nonconforming behavior or anything having to do with gender. Rather, the denial of access is due to sex. Defendants' appropriate response when it comes to these claims is not that they have not discriminated on the basis of sex, but that they have not done so unlawfully because sex discrimination is permissible in these contexts. ${ }^{132}$ Whether transgender plaintiffs have been discriminated against on the basis of sex when they are denied the bathroom or dress code or other sexbased access they seek turns on whether the sex discrimination is

(9th Cir. 2009) (same); Complaint at*7, Daskalakis v. Forever 21, Inc., $2016 \mathrm{WL}$ 4487747 (E.D.N.Y. Aug. 25, 2016) (No. 15-CV-1768), 2015 WL 1531240 (rejecting claim of transgender employee designated male at birth seeking right to comply with female dress code); Creed v. Family Express Corp., No. 3:06-CV-465RM, 2009 WL 35237, at *10 (N.D. Ind. Jan. 5, 2009) (same).

131. See infra Part IV.

132. See, e.g., Brief for Petitioner at 34, Harris III, 140 S. Ct. 1731 (2020) (mem.) (No. 18-107), 2019 WL 3958416 ("While the employer in Price Waterhouse acted based on a stereotype about people of one sex, the decision challenged here-Harris's choice to apply a sex-specific policy based on sex instead of gender identity-rests solely on the category of sex itself."); Whitaker v. Kenosha Unified Sch. Dist. No. 1 Bd. of Educ., 858 F.3d 1034, 1048 (7th Cir. 2017) ("The School District argues that even under a sex-stereotyping theory, Ash cannot demonstrate a likelihood of success on his Title IX claim because its policy is not based on whether the student behaves, walks, talks, or dresses in a manner that is inconsistent with any preconceived notions of sex stereotypes. Instead, it contends that as a matter of law, requiring a biological female to use the women's bathroom is not sex-stereotyping."); Complaint at *9, Daskalakis, 2016 WL 4487747 (No. 15-CV-1768) (alleging that employer stated, "[t]he male dress code is different from the female dress code, and you're still a male until you change your birth certificate" in a Title VII case brought by a transgender plaintiff designated male at birth seeking the right to comply with the female dress code). 
lawful. ${ }^{133}$ Note that none of this has to do with gender. The gender nonconformity doctrine thus typically has not helped plaintiffs in these cases. ${ }^{134}$

We can see this in the Tenth Circuit case Etsitty v. Utah Transit Authority, which considered the claim of a transgender truck driver designated male at birth who had begun to transition by taking hormones but had not yet completed gender-confirming surgery.135 Soon after being hired, the plaintiff began wearing makeup, jewelry, and acrylic nails to work and began using female restrooms en route. ${ }^{136}$ The employer terminated the plaintiff for using the women's restroom. 137

While the court acknowledged that "[i]t may be that use of the women's restroom is an inherent part of one's identity as a male-tofemale transsexual and that a prohibition on such use discriminates on the basis of one's status as a transsexual," it explained that the plaintiff cannot hang her hat on this, as her claim of discrimination must be based not in "her transsexuality per se," but in "the Price Waterhouse theory of protection as a man who fails to conform to sex

133. See Harris II, 884 F.3d 560, 573 (6th Cir. 2018) ("Our question is instead whether the Funeral Home could legally terminate Stephens, notwithstanding that she fully intended to comply with the company's sex-specific dress code, simply because she refused to conform to the Funeral Home's notion of her sex."). The answer to this question should turn on whether the harm of the obviously sex discriminatory policy is substantial enough to amount to prohibited discrimination, or, alternatively, whether the transgender person should legally be considered the sex they identify as, such that they should be granted access to the sex-based rule on its own terms. See infra notes 250-55 and accompanying text for further discussion.

134. See Etsitty, 502 F.3d at 1224 (rejecting the claim under both Title VII and the Equal Protection Clause that Price Waterhouse "requires employers to allow biological males to use women's restrooms," because "[u]se of a restroom designated for the opposite sex does not constitute a mere failure to conform to sex stereotypes"); Kastl, 325 F. App' $x$ at 493-94 (despite acknowledging that "it is unlawful to discriminate against a transgender (or any other) person because he or she does not behave in accordance with an employer's expectations for men or women," nonetheless holding that an employer's ban on a transgender plaintiff's use of a women's restroom did not constitute sex discrimination); Johnson v. Fresh Mark, Inc., 98 F. App'x 461, 462 (6th Cir. 2004) (per curiam) (affirming without explanation the district court's dismissal of a transgender worker's Title VII sex discrimination claim based on the employer's requirement that she use the men's rather than the women's restroom); Creed, $2009 \mathrm{WL}$ 35237, at *10 (rejecting Title VII claim brought by transgender plaintiff designated male at birth who was terminated for failing to comply with male dress code, and explaining that the plaintiff, "a man who fails to conform to sex stereotypes," still had to comply with it).

135. 502 F.3d at 1218.

136. Id. at 1219.

137. Id. 
stereotypes."138 The Court rejected the view that Price Waterhouse "requires employers to allow biological males to use women's restrooms," because "[u]se of a restroom designated for the opposite sex does not constitute a mere failure to conform to sex stereotypes."139 The gender nonconformity doctrine's premise that plaintiffs retain their sex and fail to conform their gender to it means that so long as sex classifications are unchallenged, the doctrine will not help transgender plaintiffs.

Note that transgender plaintiffs do not always lose in sex classification cases under the gender nonconformity theory. While there is a strong legal argument that transgender persons should succeed in sex classification cases, ${ }^{140}$ success under the gender nonconformity doctrine does not withstand scrutiny. Courts have bootstrapped the per se gender nonconformity theory to consider any adverse treatment of transgender persons to be gender nonconformity discrimination. For example, in a case of a transgender student designated female at birth who sought to use the boys' bathroom, the Seventh Circuit relied on the gender nonconformity doctrine to grant relief, reasoning that the plaintiff "has alleged that the School District has denied him access to the boys' restroom because he is transgender," and "[a] policy that requires an individual to use a bathroom that does not conform with his or her gender identity punishes that individual for his or her gender non-conformance." 141

While relief would have been appropriate on an alternative theory, ${ }^{142}$ recognizing a right to use the bathroom under the gender

138. Id. at 1224 .

139. Id. at 1225 ("[A]n employer's requirement that employees use restrooms matching their biological sex does not expose biological males to disadvantageous terms and does not discriminate against employees who fail to conform to gender stereotypes."); see also Kastl, 325 F. App'x at 493-94 (explaining that transgender plaintiff states a prima facie case of sex discrimination that impermissible gender stereotypes were a motivating factor in barring transgender employee designated male at birth from women's restroom, but that employer's safety justification due to employee being the wrong sex defeated the plaintiff's prima facie case); Creed, 2009 WL 35237, at *10 (in a case rejecting the Title VII claim of a transgender plaintiff designated male at birth seeking right to comply with female dress code, explaining that the "Title VII claim must rest entirely on the theory of protection as a man who fails to conform to sex stereotypes," and that the "record contains too little evidence to permit an inference that [the employer] didn't actually terminate [the plaintiff] for th[e] legally permissible reason" of violating the dress code).

140. See infra notes 250-53 and accompanying text.

141. Whitaker v. Kenosha Unified Sch. Dist. No. 1 Bd. of Educ., 858 F.3d 1034, 1049-50 (7th Cir. 2017) (addressing claim under Title IX and the Equal Protection Clause).

142. See infra notes $250-55$ and accompanying text. 
nonconformity theory is wrong and confusing. The school classified students on the basis of sex under a sex discriminatory policy that was not challenged. ${ }^{143}$ As Etsitty explained, the student was denied access to the boy's bathroom because he was considered a girl.144 This is discrimination on the basis of sex, not gender. ${ }^{145}$ To the extent a transgender student is punished because transgender students and not cisgender students are required to use a bathroom that does not conform with their sex identity, this treatment is not because she is considered a masculine girl; it is simply because she is considered a girl. ${ }^{146}$ All students considered female are required to use the girls' restroom; all students considered male are required to use the boys' restroom. This was true regardless of any students' gender performance and thus was not discrimination for failure to conform gender to sex.

Losses in sex classification cases are no small thing. They are not limited to bathrooms and dress codes. ${ }^{147}$ There is still quite a long list of areas aside from bathrooms and dress codes that are lawfully sex segregated, such as education, the military, prisons, and athletics. ${ }^{148}$ As transgender persons seek access to more sex segregated spaces based on their identified, rather than birth-designed, sex, the harm of analyzing transgender discrimination as a matter of gender nonconformity will only compound.

\section{B. Pyrrhic Victories: Losing While WinNing}

This Section turns to the gender performance cases, which are those that involve claims of discrimination against transgender persons for how masculine or feminine they appear and behave. In these cases, transgender persons have been fit within the mold of gender nonconforming plaintiffs of the past, and thus the gender nonconformity doctrine has largely led to victories for transgender

143. Whitaker, 858 F.3d at 1048.

144. See supra notes $124-25$ and accompanying text.

145. See Etsitty v. Utah Transit Auth., 502 F.3d 1215, 1224 (10th Cir. 2007) (holding that " $[\mathrm{u}]$ se of a restroom designated for the opposite sex does not constitute a mere failure to conform to sex stereotypes").

146. Whitaker, 858 F.3d at 1048 ("The School District argues that even under a sexstereotyping theory, Ash cannot demonstrate a likelihood of success on his Title IX claim because its policy is not based on whether the student behaves, walks, talks, or dresses in a manner that is inconsistent with any preconceived notions of sex stereotypes. Instead, it contends that as a matter of law, requiring a biological female to use the women's bathroom is not sex-stereotyping.").

147. See sources cited supra note 130.

148. See supra note 21. 
plaintiffs. ${ }^{149}$ For this reason, it is understandable that transgender advocates have relied on this theory. ${ }^{150}$ But the view of being transgender on which these victories are premised is in stark conflict with substantial medical and legal authority. Applying the gender nonconformity doctrine does harm by assuming and reifying contested views of sex, gender, and transgender status that undermine transgender persons' claims in the sex classification cases and their own sense of identity. 151

As explained above, courts treat transgender plaintiffs as gender nonconformers in the mold of Ann Hopkins: they retain the sex they were designated at birth and change their gender presentation. The application of the gender nonconformity doctrine to transgender plaintiffs is thus premised in particular understandings of sex, gender, and transgender status. As to the nature of sex, courts treat it as something that once designated at birth is fixed, at a minimum until surgery. ${ }^{152}$ While the doctrine must presume this notion of sex to work (i.e., for a transgender person who changes her gender presentation to fail to conform her new gender to her sex), sometimes courts have made it explicit. For example, in a case addressing the sex

149. See sources cited supra notes 101-03.

150. While this Article often highlights the errors of courts in developing and applying legal doctrine, advocates of course play a role in framing cases and supplying arguments that courts rely on. This Article focuses on the fact that these errors occur and finding a way to remedy them rather than their cause.

151. See Sharon M. McGowan, Working with Clients To Develop Compatible Visions of What It Means To "Win" a Case: Reflections on Schroer v. Billington, 45 HARV. C.R.-C.L. L. REV. 205, 205 (2010) (quoting transgender female plaintiff Diane Schroer as stating "I haven't gone through all this only to have a court vindicate my rights as a gender non-conforming man."). This brings its own set of harms. See, e.g., Young, supra note 14 , at 12 (arguing that "affirming that a transgender woman is a woman legitimizes her identity" and "signals she is worthy of equal dignity"); Stephanie Julia Kapusta, Misgendering and Its Moral Contestability, 31 HYPATIA 502, 504-05 (2016) (arguing that classifying a transgender woman as a man "denie[s her] participation in shaping those descriptions of herself" and "undermines self-respect," that is "the worth a person recognizes in her own agency and her own life plans").

152. See, e.g., Harris II, 884 F.3d 560, 576-77 (6th Cir. 2018) ("Thus, an employer cannot discriminate on the basis of transgender status without imposing its stereotypical notions of how sexual organs and gender identity ought to align. There is no way to disaggregate discrimination on the basis of transgender status from discrimination on the basis of gender nonconformity, and we see no reason to try." (emphasis added)); Schwenk v. Hartford, 204 F.3d 1187, 1202 (9th Cir. 2000) ("Male-to-female transsexuals, as anatomical males whose outward behavior and inward identity did not meet social definitions of masculinity, were denied the protection of Title VII by these courts because they were the victims of gender, rather than sex, discrimination." (emphasis added)). For further discussion of the role of anatomy and surgical anatomical changes in the legal designation of sex under sex discrimination law, see supra notes 74, 86 . 
discrimination claim of a transgender plaintiff designated male at birth, one court stated that "[a]lthough the court has referred to [the plaintiff] as female in this opinion in deference to her self-identification, she must be considered male for the purposes of Title VII" because "Congress intended the term 'sex' to mean 'biological male or biological female."'153

Given that discrimination turns on the intent of the discriminator, ${ }^{154}$ one might wonder whether the application of the gender nonconformity doctrine to transgender plaintiffs could be based in the discriminator's perception of gender nonconformity. 155 Under this type of "regarded as" theory of discrimination, it is not the court but the discriminator who has regarded the transgender plaintiff as a gender nonconforming person. But this has not been the basis for courts' decisions. ${ }^{156}$ While courts have made some gesture towards the

153. Creed v. Family Express Corp., No. 3:06-CV-465RM, 2009 WL 35237, at *8 (N.D. Ind. Jan. 5, 2009) (citation and internal quotation marks omitted); see also Lopez v. River Oaks Imaging \& Diagnostic Grp., Inc., 542 F. Supp. 2d 653, 655 (S.D. Tex. 2008) (explaining that "while she is biologically male, she lives her life as a woman"); Mitchell v. Axcan Scandipharm, Inc., No. 05-243, 2006 WL 456173, at *2 (W.D. Pa. Feb. 17, 2006) (stating the following of a transgender plaintiff designated male at birth, despite the plaintiff's legal name change and changes to her driver's license, voter registration card, and Social Security documents indicating plaintiff is female: "[h]aving included facts showing that his failure to conform to sex stereotypes of how a man should look and behave was the catalyst behind defendant's actions, plaintiff has sufficiently pleaded claims of gender discrimination" (emphasis added)).

154. See Ledbetter v. Goodyear Tire \& Rubber Co., 550 U.S. 618, 624 (2007) (explaining that the "the central element of [a disparate treatment claim under Title VII] is discriminatory intent" by the employer); Watson v. Fort Worth Bank \& Tr., 487 U.S. 977, 1002 (1998) (Blackmun, Brennan, \& Marshall, JJ., concurring) ("[A] disparatetreatment challenge [under Title VII] focuses exclusively on the intent of the employer."); Pers. Adm'r of Mass. v. Feeney, 442 U.S. 256, 277 (1979) (making clear that an Equal Protection claim challenging law as sex discriminatory turns on the discriminatory intent of the legislature).

155. See generally Angela Onwuachi-Willig \& Mario L. Barnes, By Any Other Name?: On Being "Regarded as" Black, and Why Title VII Should Apply Even If Lakisha and Jamal Are White, 2005 WIS. L. REV. 1283 (discussing the "regarded as" theory of discrimination in the context of race).

156. See generally Jason Lee, Lost in Transition: The Challenges of Remedying Transgender Employment Discrimination Under Title VII, 35 HARV. J.L. \& GENDER 423, 445 (2012) (noting that "many courts ... make broad, descriptive claims about the actual gender nonconformity of their respective transgender plaintiffs" rather than relying on a "regarded as" theory). And it is not settled whether this theory of discrimination is even available under various laws. See infra note 261 and accompanying text for further discussion. By contrast, advocates have sometimes taken care to present the theory on the basis of employer's motives. See, e.g., United States v. Se. Okla. State Univ., No. CIV-15-324-C, 2015 WL 4606079, at *2 (W.D. Okla. July 10, 2015) (making clear that “Defendants' actions as alleged by Dr. Tudor occurred because ... Defendants 
discriminator's perception of the plaintiff's gender nonconformity, these cases still state and apply the doctrine as premised in actual gender nonconformity. 157 The per se approach leaves no doubt that courts are treating transgender persons as gender nonconformers as a matter of fact rather than as a matter of perception. This approach turns not on the facts of the particular case (i.e., what was in any particular decision maker's mind), but on an across-the-board assumption about the nature of being transgender-that it is by definition a matter of retaining one's sex designated at birth and changing only one's gender. 158

regarded her as male" in a sex discrimination case raised by a transgender woman (emphasis added)).

157. The Ninth Circuit has stated that "[w] hat matters, for purposes of this part of the Price Waterhouse analysis, is that in the mind of the perpetrator the discrimination is related to the sex of the victim: here, for example, the perpetrator's actions stem from the fact that he believed that the victim was a man who 'failed to act like' one." Schwenk v. Hartford, 204 F.3d 1187, 1202 (9th Cir. 2000) (emphasis added). It is not clear whether Schwenk's reference to whether the perpetrator "believed that the victim was a man who failed to act like one" refers to the perpetrator's belief about the victim's sex-whether or not the plaintiff was a man or a woman-or the perpetrator's belief about the victim's gender-whether or not the plaintiff acted like a man should. Id. at 1202 (internal quotation marks omitted). The court otherwise assumed that the transgender plaintiff designated male at birth was a man, as a matter of fact, $i d$. at 1201 (describing "[m]ale-to-female transsexuals" as "males"), and as a matter of law, id. at 1200 (deciding as a predicate question to plaintiff's claim "whether the Act applies to males"), and explained the doctrine as about actual rather than perceived gender nonconformity, id. at 1202 ("Discrimination because one fails to act in the way expected of a man or woman is forbidden under Title VII."). Smith also gestures at the "regarded as" theory, but the court makes clear that it was premising its decision on actual nonconformity. Compare Smith v. City of Salem, 378 F.3d 566, 573-74 (6th Cir. 2004) ('Smith alleges that Defendants' discrimination was motivated by his appearance and mannerisms, which Defendants felt were inappropriate for his perceived sex." (emphasis added)), and Glenn v. Brumby, 663 F.3d 1312, 1316 (11th Cir. 2011) ("A person is defined as transgender precisely because of the perception that his or her behavior transgresses gender stereotypes." (emphasis added)), with Smith, 378 F.3d at 568 (describing transgender plaintiff designated male at birth as "biologically and by birth a male" and applying Price Waterhouse to the plaintiff because "employers who discriminate against men because they do wear dresses and makeup, or otherwise act femininely, are also engaging in sex discrimination, because the discrimination would not occur but for the victim's sex" (emphasis added)), and Glenn, 663 F.3d at 1316 ("[T]he very acts that define transgender people as transgender are those that contradict stereotypes of gender-appropriate appearance and behavior."). The only court to clearly rely on a "regarded as" theory did so on a motion to dismiss based upon the allegations in the complaint. See Se. Okla. State Univ., 2015 WL 4606079, at *2 ("Here, it is clear that Defendants' actions as alleged by Dr. Tudor occurred because she was female, yet Defendants regarded her as male. Thus, the actions Dr. Tudor alleges Defendants took against her were based upon their dislike of her presented gender." (emphasis added)).

158. See supra notes 102-06 and accompanying text. 
If being transgender is simply a matter of changing gender rather than designated sex, as courts have understood it under the gender nonconformity doctrine, then transgender plaintiffs will have a much harder time in sex classification cases. A transgender person designated male at birth like Stephens is simply an effeminate man, not a woman, and will be in a much weaker position arguing for the right to use the women's bathroom or comply with the female dress code. ${ }^{159}$

The assumption that transgender plaintiffs are gender nonconformers who are changing their gender rather than their designated sex assumes a view of sex that is highly contested, both as a matter of the latest medical authority and as a matter of law. While the "old" view of sex turns on a designation made at birth, typically based in anatomy, ${ }^{160}$ the "new" view ${ }^{161}$ of sex is premised on an "internal, deeply held sense" of one's identity. ${ }^{162}$ Under this view, sex "comes from the brain, not the body," from "between your ears, not between

159. See infra Part IV.B for a theory of how such a person could nonetheless prevail in such cases on a theory of sex discrimination. Regardless of the strength of this argument, it will be harder to convince judges-or the public - that men should be allowed to use the women's bathroom and that women should be allowed to use the men's bathroom.

160. See supra notes $70,83,143,145$ and accompanying text.

161. I call this view "new" because it has gained wide acceptance more recently, but the medical and legal recognition of this view is by no means entirely new. See, e.g., Ulane v. E. Airlines, Inc., 581 F. Supp. 821, 823-24 (N.D. Ill. 1983) (crediting expert medical testimony that "sex is at least in part a question of self-perception"), rev'd, 742 F.2d 1081 (7th Cir. 1984).

162. GLAAD MEDIA REFERENCE GuIDE, supra note 6 (defining "[g]ender [i]dentity" as "[a] person's internal, deeply held sense" of whether they are "man or a woman"); AM. PSYCHIATRIC ASS'N, supra note 86, at 822 (defining "gender identity" as "a category of social identity that refers to an individual's identification as male, female, or ... [another] category"); Boyden v. Conlin, 341 F. Supp. 3d 979, 986 (W.D. Wis. 2018) ("For purposes of medical diagnosis, as well as increasingly for purposes of common usage, 'gender identity' is the internal core sense of one's own sex, such as male or female."); Lusardi v. McHugh, EEOC Appeal No. 0120133395, 2015 WL 1607756, at *6 (Apr. 1, 2015) ('Gender identity' refers to a person's internal sense of being male or female (or, in some instances, both or neither)."); Guidance Regarding the Employment of Transgender Individuals in the Federal Workplace, U.S. OFF. PERSONNEL MGMT., https:// web.archive.org/web/20180213144755/https://www.opm.gov/policy-data -oversight/diversity-and-inclusion/reference-materials/gender-identity-guidance ("Gender identity is the individual's internal sense of being male or female or an identity other than the traditional definitions of male or female."); Expert Declaration of Randi Ettner, Ph.D, at 11, Carcaño v. McCrory, 203 F. Supp. 3d 615 (M.D.N.C. 2016) (No. 1:16-cv-236) [hereinafter Ettner] ('The term 'gender identity' is a well-established concept in medicine, referring to one's sense of oneself as belonging to a particular gender. All human beings develop this elemental internal view: the conviction of belonging to a particular gender, such as male or female."). 
your legs." 163 While the literature refers to this internal sense as one's "gender identity," under the terms of sex discrimination law, it is a marker of sex-who one is-rather than of gender-what one does. ${ }^{164}$ And despite this confusing terminology, proponents of the new view of sex make clear that gender identity is determinative of legal sex. ${ }^{165}$ To be clear, the Article does not intend to endorse any particular view of sex, but highlights this new view of sex to demonstrate how the gender nonconformity doctrine's unquestioning acceptance of birth-designated sex has been seriously called into question and, at the very least, requires serious scrutiny.

A key example of the new view of sex arises in a set of related cases challenging a North Carolina law that required bathrooms and other similar sex-segregated facilities in public agencies to be "designated for and only used by" persons based on the "biological sex" listed on their birth certificate. ${ }^{166}$ In one of the cases, the plaintiffs submitted expert evidence of one's internal sense of identity as the primary determinant of one's sex. ${ }^{167}$ One expert opined: "[f]rom a medical perspective, the appropriate determinant of sex is gender identity[,]" 168 which is "a person's inner sense of belonging to a particular gender [sex], such as male or female."169 Because many people's gender identity matches their external genitalia, the sex they are assigned at birth will match their gender identity. ${ }^{170}$ But, as in cases of

163. Denise Grady, Anatomy Does Not Determine Gender, Experts Say, N.Y. TimES (Oct. 22, 2018), https://www.nytimes.com/2018/10/22/health/transgender-trump -biology.html [https://perma.cc/PP57-B687] (quoting leading expert as stating, "[t]he idea that a person's sex is determined by their anatomy at birth is not true, and we've known that it's not true for decades").

164. I discuss this linguistic confusion and its relationship to the doctrine further below. See infra notes 166-71 and accompanying text.

165. Expert Declaration of Deanna Adkins, M.D. ๆๆ 32-33, Carcaño, 203 F. Supp. 3d 615 (No. 1:16-cv-00236) [hereinafter Adkins] ("[G]ender identity is the only medically supported determinant of sex when sex assignment as male or female is necessary.... Gender identity does and should control when there is a need to classify an individual as a particular sex.").

166. See Carcaño v. Cooper, 350 F. Supp. 3d 380, 397 (M.D.N.C. 2018) (granting in part and denying in part defendants' motion to dismiss); Carcaño v. McCrory, $203 \mathrm{~F}$. Supp. 3d 615, 621, 632-40 (M.D.N.C. 2016) (granting plaintiffs' motion for preliminary injunction based on "[the Department of Education]'s guidance defining 'sex' to mean gender identity").

167. Adkins, supra note 165 , ๆ 8.

168. Id. $\uparrow 23$. As a matter of sex discrimination doctrine, the identity to which Adkins refers is actually sex identity rather than gender identity. I discuss this further below.

169. Id. $\uparrow 15$.

170. Id. ๆ 26. 
transgender persons, when there is not a "complete alignment among sex-related characteristics[,]" including internal "gender identity[,]" then "a more careful consideration of sex assignment is needed." 171 In these cases, "[m]edicine and science require" that the carefully considered basis of sex assignment be internal "gender identity rather than other sex characteristics." 172 Indeed, "[i]t is counter to medical science to use chromosomes, hormones, internal reproductive organs, external genitalia, or secondary sex characteristics to override gender identity for purposes of classifying someone as male or female."173

Under the new view of sex, a transgender person designated male at birth who identifies as female and adopts a feminine gender presentation is a woman who is conforming her gender to her sex, not an effeminate man who fails to conform his gender to his sex. This is so regardless of whether this person has undergone surgery to change her anatomy, or indeed whether this person has undergone any particular medical treatment at all. ${ }^{174}$

This new view of sex is not so unsettling to the legal meaning of sex as it might seem. While it changes the primary determinant of sex from one's anatomy to one's internal sense of sex, it retains the distinguishing features that render sex distinct from gender in sex discrimination law: its biological basis and its immutability. Premising sex on an internal sense of identity dovetails with the traditional distinction between gender as a cultural artifact and sex as a biological dictate. ${ }^{175}$

\footnotetext{
171. Id. $₫ 25$.

172. Id.

173. Id. ๆ 33.

174. Ettner, supra note 162, ๆ 22 ("Many transgender individuals never undergo surgery.... [F] or many ... surgery is not medically necessary as dysphoria is alleviated through social role transition and hormone therapy.... [S] urgery is cost prohibitive because it is excluded from coverage under many insurance plans.... Additionally, there are several medical contraindications that ... preclude surgical treatment."); see also Lusardi v. McHugh, EEOC Appeal No. 0120133395, 2015 WL 1607756, at *8 n.3 (Apr. 1, 2015) ("Gender reassignment surgery is in no way a fundamental element of a transition. Transitions vary according to individual needs and many do not involve surgery at all... Some individuals, however, will not pursue some (or any) forms of medical treatment because of their age, medical condition, lack of funds, or other personal circumstances.").

175. See supra notes $49-51$ and accompanying text. There has never been agreement among courts that the notion of biological sex refers only to anatomy rather than to some broader understanding of biology. See Holloway v. Arthur Anderson \& Co., 566 F.2d 659, 662 (9th Cir. 1977) ("[T]he term sex should be given the traditional definition based on anatomical characteristics." (emphasis added)); Ulane v. E. Airlines, Inc., 742 F.2d 1081, 1083 n.6 (7th Cir. 1984) ("Biologically, sex is defined by chromosomes, internal and external genitalia, hormones, and gonads." (emphasis added)); Ulane, 742 F.2d at 1087 ["[I]f the term 'sex' as it is used in Title VII is to mean more than biological
} 
Experts who adopt the new view of sex agree that one's internal sense of sex is based in biology. ${ }^{176}$ The new view of sex also dovetails with the traditional distinction between gender as fluid and sex as fixed.177 Again, expert proponents of this view are in agreement that one's internal sense of sex is something that one is born with and cannot be changed. 178

Indeed, numerous legal authorities that classify persons by sex have adopted the new view of sex, treating one's internal sense of identity as determinative. This can be seen perhaps most prominently in the formal legal designation of sex on things like passports and birth certificates. Since 2010, the federal government has issued passports that reflect a person's identified sex rather than birth-designated sex. ${ }^{179}$ Under the State Department's policy, transgender persons can obtain such a passport by submitting certification from a physician confirming that they have had appropriate clinical treatment for a change to their designated sex identity. ${ }^{180}$ No change to anatomy or

male or biological female, the new definition must come from Congress." (emphasis added)); cf. Dobre v. Nat'l R.R. Passenger Corp., 850 F. Supp. 284, 286 (E.D. Pa. 1993) ("The term 'sex' in Title VII refers to an individual's distinguishing biological or anatomical characteristics ...." (emphasis added)).

176. See Adkins, supra note 165, ๆ 22 ("Both post-mortem and functional brain studies that have been done on the brains of individuals with gender dysphoria show that these individuals have brain structure, connectivity, and function that do not match their birth-assigned sex."); Expert Report of Walter O. Bockting, Ph.D II 32, Schroer v. Billington, 424 F. Supp. 2d 203 (D.D.C. 2006) (No. 05CV01090) [hereinafter Bockting Report] (testifying that "gender identity can be viewed as the sex of the brain"); Grady, supra note 163 ("We know that there is a significant, durable biological underpinning to gender identity.... As far as we in the mainstream biological-medical community understand it in 2018, it is hard-wired, it is biological, it is not entirely hormonal, and we do not have identified genes, so we cannot specifically say it is genetic.").

177. See supra notes $49-51$ and accompanying text.

178. Adkins, supra note 165 , ๆ $20-21$ ("Gender identity cannot be voluntarily altered including for individuals whose gender identity does not align with their birthassigned sex....[E]vidence strongly suggests that gender identity is innate or fixed at a young age."); Bockting Report, supra note 176 ("Gender identity ... once established, cannot be changed."); see also Grady, supra note 163 (citing medical reports on people who were born in the 1950s and 1960s with birth defects involving their genitals who were surgically "made female" as babies, but nonetheless, more than half ended up identifying as male).

179. Change of Sex Marker, U.S. DEP'T ST., https://travel.state.gov/content/travel/ en/passports/apply-renew-passport/change-of-sex-marker.html [https://perma.cc/ 534S-BTPF] (directing how to change sex designation on a passport); see also Young, supra note 14, at 26 ("[T]he U.S. Department of State issues passports that reflect a binary change in sex.").

180. Change of Sex Marker, supra note 179 (requiring only a "medical certification that indicates you have had appropriate clinical treatment for transition to male or female, or are in the process of transition to male or female"). 
any other specific medical treatment is required. ${ }^{181}$ Almost twenty states now allow sex designations on birth certificates to be changed without any change in anatomy or other specific medical treatment. 182 States like California allow the sex on a birth certificate to be changed "to match the sex specified on your birth certificate to your sex identity." 183 And courts have applied this state law allowing changes to sex designations of birth certificates to determine a transgender person's legal sex for purposes of federal employment law.184 It would be strange indeed if sex equality law were to undermine the progress made in other areas of law recognizing that being transgender can entail a change to one's designated sex.

To be sure, not everyone in the medical community agrees with this view of sex. ${ }^{185}$ And, to be clear, the argument here is not that the

181. Id. ("A description of specific treatments is not required in the medical certification. The certification is based on your physician's clinical assessment of your treatment.").

182. See Changing Birth Certificate Sex Designations: State-by-State Guidelines, LAMBDA LEGAL (Sept. 17, 2018), https://www.lambdalegal.org/know-your-rights/ article/trans-changing-birth-certificate-sex-designations [https://perma.cc/6UML

-987X]. For a sampling of the language of specific state laws, see, for example, ID Documents Center / Delaware, NAT'L CTR. FOR TRANSGENDER EQuAL. (May 2020), https:// transequality.org/documents/state/delaware [https://perma.cc/4RFF-HD2T] ("Delaware will amend the gender marker on an individual's birth certificate upon receipt of an affidavit from a medical or mental health professional stating that the applicant has had surgical, hormonal, psychological or other treatment appropriate for the individual for the purpose of gender transition."); ID Documents Center / Maryland, NAT'L CTR. FOR TRANSGENDER EQUAL. (May 2020), https://transequality.org/documents/ state/maryland [https://perma.cc/SV9E-YFBN] ("The Maryland Department of Health and Mental Hygiene will update the gender marker on a certificate of birth upon receipt of certification from a licensed healthcare provider that the applicant has undergone surgical, hormonal, or other treatment appropriate for the purpose of sex transition. A new certificate of birth will be issued and will not be marked as amended."); ID Documents Center / Nevada, NAT'L CTR. FOR TRANSGENDER EQUAL. (May 2020), https:// transequality.org/documents/state/nevada [https://perma.cc/JHC9-EZ4R] ("Vital

Records will issue a new birth certificate with a corrected gender of male, female, or X upon receipt of two affidavits reflecting an individual's gender."); see also Young, supra note 14, at 26 ("Today, every single state permits transgender persons to amend identity documents, like driver's licenses, to reflect a change in sex.").

183. ID Documents Center / California, NAT'L CTR. FOR TRANSGENDER EQUAL. (May 2020), https://transequality.org/documents/state/california [https://perma.cc/ 3XDX-XKK4] (emphasis added).

184. See, e.g., Radtke v. Misc. Drivers \& Helpers Union Loc. No. 638, 867 F. Supp. 2d 1023, 1033, 1036 (D. Minn. 2012) (looking to a newly issued birth certificate allowed under state law to recognize a transgender person's revised legal sex in adjudicating a claim under the federal Employment Retirement Income Security Act).

185. See, e.g., Boyden v. Conlin, 341 F. Supp. 3d 979, 986 (W.D. Wis. 2018) (discussing the dispute between the medical experts on the nature of gender identity (i.e., one's internal sense of sex), noting that "Plaintiffs contend that gender identity is innate and 
meaning of sex in statutes that prohibit discrimination on the basis of sex — such as Title VII-must include "gender identity," although there is at least a colorable argument that it does. ${ }^{186}$ My point is instead that, at the very least, medical and legal authority on the sex of transgender persons is far more contested than the settled picture that transgender discrimination jurisprudence under the gender nonconformity doctrine now presents: that sex assigned at birth is fixed, unerring, and unchangeable (at least until surgical anatomical changes, and maybe forever). ${ }^{187}$ Treating transgender plaintiffs as gender nonconformers bakes in this view of sex, to the detriment of transgender rights.

So even when transgender plaintiffs win under the gender nonconformity doctrine in gender performance cases, these are Pyrrhic victories that undermine the cause of transgender plaintiffs in the sex classification cases. While we might view this as a worthwhile tradeoff-victory in the gender performance cases at the cost of loss in the sex classification cases-this is a bad bargain. These losses are serious, 188 and, as this Article later shows, the tradeoff is unnecessary. 189

\section{Undermining PROTECTION FOR GENDER NONCONFORMity}

The foregoing Sections have focused on the harms of treating transgender plaintiffs as gender nonconformers from the perspective of transgender rights. This Section addresses harms from the perspective of gender nonconforming plaintiffs and the consequences for gender nonconformity protection. Treating transgender persons as gender nonconformers makes it more difficult for gender nonconformers to succeed in their claims, undermining protection for gender nonconformity.

generally considered to be an immutable characteristic," whereas "Defendants dispute this, instead positing that sex is immutable, whereas gender identity is a developmental process"); $c f$. Maayan Sudai, Toward a Functionalist Analysis of 'Sex' in Federal Antidiscrimination Law, 42 HARV. J.L. \& GENDER 421, 423 (2019) ("[T]he search for a descriptively accurate definition of 'sex' in the law, based on scientific knowledge, is futile.").

186. The EEOC has adopted this view. See, e.g., Lusardi v. McHugh, EEOC Appeal No. 0120133395, 2015 WL 1607756, at*7-8 (Apr. 1, 2015) (holding that under Title VII, an employee's sex is determined by her gender identity and thus that an employer must allow an employee to use the bathroom that accords with that sex).

187. See supra notes $70,83,141-45$ and accompanying text.

188. See supra note 139 and accompanying text.

189. See infra Part IV.B for an alternative theory that can recognize transgender discrimination as sex discrimination without having to make this tradeoff. 
Scholars writing in this area have noted a troubling trend: as transgender plaintiffs were winning cases under the gender nonconformity doctrine, traditional gender nonconformers were losing them. ${ }^{190}$ Even after Price Waterhouse, courts have upheld sex discriminatory dress codes when gender nonconformers have challenged them. ${ }^{191}$

The prime example cited of the failure of gender nonconforming cisgender plaintiffs is the "infamous" case of Jespersen v. Harrah's Casino, with the Ninth Circuit panel decision arriving the same year as Smith, and the en banc decision affirming it two years later. ${ }^{192}$ The plaintiff in that case challenged her employer's policy of mandating make-up for women while banning it for men on the ground that it subjectively "prohibited [her] from doing [her] job" because it "took away [her] credibility as an individual and as a person," and that it objectively stereotyped women. ${ }^{193}$ The court rejected her claim under precedents that have accepted sex discriminatory grooming codes so long as they do not impose unequal burdens on men and women, and so long as they are not motivated by sex stereotypes. ${ }^{194}$

The transgender victory/cisgender failure trend may be overstated, because scholars have to some extent been comparing apples and oranges. To understand this, we must return to the distinction between gender performance cases and sex classification cases. At least some of the cases that scholars rely on to highlight the relative success

190. See Case, supra note 28, at 1352 ("[A]s courts relying on Hopkins became more receptive to claims by sexual minorities (including, especially, effeminate men, gay men, and transgender plaintiffs), they paradoxically became less receptive to plaintiffs who more closely resembled Ann Hopkins herself-women who asserted no identity as a sexual minority, but whose gender presentation veered slightly more in a masculine direction than suited their employers."); id. at 1354 ("Although the progress of claims brought by transgender and gay plaintiffs under Title VII has shown a positive trend, ... a trend in the opposite direction has emerged in cases challenging sex-specific grooming codes brought by plaintiffs who did not identify as transgender.").

191. See, e.g., Jespersen v. Harrah's Operating Co., 444 F.3d 1104, 1106 (9th Cir. 2006) (en banc) (upholding termination of female employee for failing to comply with her employer's sex discriminatory appearance code, which required women to wear makeup, on the theory that the record did not create "any triable fact" indicating the requirement perpetuated problematic sex stereotypes or imposed unequal burdens on men and women); see also Harper v. Blockbuster Ent. Corp., 139 F.3d 1385, 1386 (11th Cir. 1998) (upholding an employer's sex discriminatory appearance code); Tavora v. N.Y. Mercantile Exch., 101 F.3d 907, 908 (2d Cir. 1996) (per curiam) (upholding a sex discriminatory dress code relating to hair length).

192. Case, supra note 28, at 1336; see also Yuracko, supra note 14, at 792-98.

193. Jespersen, 444 F.3d at 1108.

194. See id. 
of transgender plaintiffs are gender performance cases, like Smith,195 whereas the cases that scholars rely on to highlight the relative failure of cisgender plaintiffs are sex classification cases, like Jespersen. 196 Still, to the extent that some transgender plaintiffs have had success even in sex classification cases-dress code cases and bathroom cases-whereas cisgender plaintiffs have not,197 this is a striking trend.

Scholars have disagreed about the reasons behind the divergent trajectory of transgender and cisgender cases under the gender nonconformity doctrine. Professor Case has attributed it to cultural shifts in societal willingness to accept gender nonconformity within the cisgender population combined with increasing acceptance of what she calls "identitarian" claims based in transgender, gay, or lesbian status. ${ }^{198}$ Professor Kimberly Yuracko has explained this as a product of

195. See Case, supra note 28, at 1346-47 (referencing transgender gender performance cases following Smith v. City of Salem, 378 F.3d 566 (6th Cir. 2004), such as Barnes v. City of Cincinnati, 401 F.3d 729, 737 (6th Cir. 2005)); Yuracko, supra note 14, at 765-69 (collecting transgender gender performance cases, including Smith, 378 F.3d at 568).

196. See Case, supra note 28, at 1336; Yuracko, supra note 14 , at 770 . The circuit split that justified granting certiorari in Harris III is thus overstated. See Petition for a Writ of Certiorari at 15, Harris III, 139 S. Ct. 1599 (2019) (mem.) (No. 18-107), 2018 WL 3572625 [hereinafter Harris Petition] ("The circuits are irreconcilably split on whether 'sex' in Title VII ... includes 'transgender status."'). In coming to this conclusion, the petitioners cite the conflicts between Etsitty v. Utah Transit Authority, 502 F.3d 1215 (10th Cir. 2005), and Sommers v. Budget Marketing, Inc., 667 F.2d 748 (8th Cir. 1982), which both denied protection but in sex classification cases about which bathroom transgender persons can use, Harris Petition, supra, at 16, and Glenn v. Brumby, 663 F.3d 1312 (11th Cir. 2011), and Schwenk v. Hartford, 204 F.3d 1187 (9th Cir. 2000), which both granted protection but in gender performance cases. Harris Petition, supra, at 18 . To the extent there is a split among circuits on transgender cases, it can largely be explained by the different nature of the cases: gender performance cases, where transgender plaintiffs have won, and sex classification cases, where transgender plaintiffs have mostly lost.

197. Compare Harris II, 884 F.3d 560, 572 (6th Cir. 2018) (accepting transgender plaintiff's claim of sex discrimination for firing due to non-compliance with employer's sex-specific dress code), with Jespersen, 444 F.3d at 1106 (rejecting cisgender plaintiff's challenge to sex-specific dress code). See generally Case, supra note 28, at 1364 ("The post-millennial trend in school dress code cases suggest[s] that students objecting to sex-specific appearance rules seem to have a far clearer road to victory if they claim an identity as transgender, gay, or lesbian rather than simply raising an objection to being stereotyped on grounds of sex.").

198. See Case, supra note 28, at 1362 ("Between the time Hibbs was decided and the time Jespersen reached the Ninth Circuit en banc, the tide may have shifted back toward increasing acceptance of differentiating in law (and in society) between males and females."). Case notes, for example, that in 1996, there were "fewer than half a dozen sex-segregated public schools" in the United States, but that "[b]y 2006, there were more than 200." Id. Furthermore, Case points out that trends in children's 
the doctrine itself, which she sees as a balancing test that compares the harms that plaintiffs suffer under forced gender conformity with the costs the regulated entity endures from having to adjust its gender expectations. ${ }^{199}$ She argues that transgender plaintiffs can present stronger evidence of the medical need for nonconformity and the harm they will suffer if not granted relief, whereas the costs of conformity for cisgender plaintiffs seem to be simply a matter of "transient personal preferences" and thus minimal by comparison. ${ }^{200}$

This Article offers a different explanation. Treating transgender plaintiffs as gender nonconformers confuses courts and makes cisgender plaintiffs' claims seem weak by comparison. These problems stem not from features of the doctrine, as Yuracko suggests, ${ }^{201}$ or from the respective merits of the cases according to social trends, as Case suggests, ${ }^{202}$ but from wrongly applying the gender nonconformity doctrine to transgender plaintiffs, who should not be understood as gender nonconformers at all. Treating transgender and cisgender claims under the same doctrine necessarily makes them referents for each other, both formally, as legal precedents, and informally, as referents in judges' minds. Cisgender plaintiffs fare poorly under such a comparison.

I do not go so far as to stake a causal claim that the success of transgender plaintiffs has led to the failure of cisgender plaintiffs.

clothing show that "[b]etween 1965 and 1985, boys sported long hair and wore boldly patterned shirts and pants; girls wore pants, even for school." Id. at 1363. In fact, "[n]eutral styles for infants were reduced to a very small part of the market in the mid1980 s, and by the mid-1990s styles for toddlers and young children were more gender specific than they had been in the 1950s." Id.

199. See Yuracko, supra note 14, at 791-92 ("[T]he burden shifting framework helps explain why transsexuals are succeeding ... [and] nontranssexuals are not.").

200. See id. ("Transsexuals are winning because they are able to use medical evidence of their [gender identity disorder] to convince courts that compliance with sexbased gender norms would be particularly painful and difficult for them .... [N]ontranssexual gender benders lose precisely because courts view the burden of the conformity demands imposed on them as trivial.... Without new medical evidence to the contrary, courts will continue to view [their] noncompliance as a matter of personal taste, and compliance as relatively painless."). Other scholars have also weighed in. See, e.g., Paisley Currah, Transgender Rights Without a Theory of Gender, 52 TULSA L. REV. 441, 446 (2017) (suggesting that wins in transgender cases are due to courts accepting transgender persons as their identified sex rather than their sex designated at birth); Jennifer L. Levi, Clothes Don't Make the Man (or Woman) but Gender Identity Might, 15 COLUM. J. GENDER \& L. 90, 101 (2006) (positing that the disability claims that transgender plaintiffs have raised alongside their sex discrimination claims have aided their cause).

201. See Yuracko, supra note 14, at 803-04.

202. See Case, supra note 14 , at 32 . 
Nonetheless, wrongly treating both transgender and cisgender plaintiffs as gender nonconformers may have concerning consequences for cisgender plaintiffs-and for the doctrine itself.

First, comparing transgender and cisgender cases under the same doctrine makes cisgender cases appear wanting. When transgender and cisgender cases are presented as a continuum of gender nonconformity, transgender plaintiffs are now seen as more gender nonconforming than cisgender plaintiffs like Hopkins or Jespersen. It is now the transgender plaintiff rather than the cisgender plaintiff who represents the paragon of gender nonconformity. 203 Transgender persons often enjoy an assumption of per se gender nonconformity, and courts and scholars have sometimes seen them as more extreme examples of gender nonconformity than the cisgender plaintiffs of the past. ${ }^{204}$ As transgender plaintiffs are seen to embody the claim more fully than cisgender plaintiffs, this makes cisgender cases appear weaker.

Still further, transgender plaintiffs tend to rely on evidence of a discrete psychological condition, gender dysphoria, or other objective medical or psychological evidence to establish their claims. ${ }^{205}$ If courts come to expect similar medical evidence in cisgender claims, they will not find it. Claims by cisgender plaintiffs instead turn on the subjective harm that gender conformity imposes on the plaintiff. Folding transgender plaintiffs into the gender nonconformity doctrine may thus set the bar unrealistically high for cisgender plaintiffs. ${ }^{206}$

This evidentiary difference will not only make transgender claims seem like the stronger claims, but also the more appealing claims, as they are bounded in ways that the cisgender claims are not. Because they are established by objective evidence, transgender claims are limited in number and easy to identify, administer, and cabin with proof. When it comes to cisgender claims, by contrast, it is

203. See supra Part II.C (referencing courts' view of transgender litigants as per se gender nonconformers).

204. Id.

205. See Yuracko, supra note 14, at 781 (collecting cases documenting "courts' often heavy reliance in the transsexual cases on medical evidence"); see also AM. PSYCHIATRIC ASS'N, supra note 86, at 451-54 (defining gender dysphoria).

206. The different evidentiary basis for the claims might also lead to a view that transgender plaintiffs' claims are equality claims based in immutable identity, whereas cisgender plaintiffs' claims are liberty claims based in personal preference. To the extent that the law finds claims of equality based in immutable identity more compelling than claims of liberty based in personal preference, transgender claims will have the upper hand. See generally Kenji Yoshino, The New Equal Protection, 124 HARV. L. REV. 747 (2011), for more on the distinction between liberty and equality claims. 
difficult to assess the sincerity of a subjective objection, and once adjudged sincere, to decide where to draw the line at how much subjective harm is necessary to qualify for relief. 207

Compare Bostock ${ }^{208}$ and Jespersen. ${ }^{209}$ The transgender plaintiff in Bostock, Aimee Stephens, sought the right to comply with her employer's dress code for women. ${ }^{210}$ In support of her claim, Stephens presented a medical diagnosis of gender identity disorder. ${ }^{211}$ It has been well documented across transgender discrimination cases that presenting as one's identified sex rather than one's designated sex is essential to a transgender person's health and wellbeing and is part of the accepted standard of care. ${ }^{212}$ Jespersen, a cisgender woman, sought an exception to her employer's dress code for women. ${ }^{213}$ In support of her claim, she presented her own testimony that she was uncomfortable wearing make-up. ${ }^{214}$ Courts might rightly be concerned about a deluge of litigation and difficult line-drawing problems flowing from allowing subjective objections to sex-based rules.

Cisgender plaintiffs also raise the specter of upsetting the existing order because they seek to dismantle the sex discriminatory rules they challenge. ${ }^{215}$ When cisgender plaintiffs have been offered exemptions to sex-based policies, they have rejected these offers. ${ }^{216}$ The

207. See, e.g., Jespersen v. Harrah's Operating Co., 444 F.3d 1104, 1113 (9th Cir. 2006) (en banc) (rejecting cisgender plaintiff's challenge to sex-based dress code premised on subjective evidence of harm).

208. Bostock v. Clayton Cnty., 140 S. Ct. 1731 (2020).

209. 444 F.3d at 1104.

210. Bostock, 140 S. Ct. at 1738.

211. Id.; Harris II, 884 F.3d 560, 568 (6th Cir. 2018).

212. See, e.g., Smith v. City of Salem, 378 F.3d 566, 568 (6th Cir. 2004) (noting that doing so is "in accordance with international medical protocols for treating GID [gender identity disorder]"); see also Yuracko, supra note 14, at 791 (arguing that "transgender plaintiffs are able to use medical evidence of their GID to convince courts that compliance with [birth-designated] sex-based gender norms would be particularly painful and difficult for them").

213. Jespersen, 444 F.3d at 1105-06.

214. Id. at 1108 ("[Jespersen] found the makeup requirement offensive, and felt so uncomfortable" wearing makeup that she found it "interfered with her ability to perform as a bartender.").

215. See, e.g., Complaint at 2, Jespersen v. Harrah's Operating Co., 280 F. Supp. 2d 1189 (D. Nev. 2002) (No. CV-N-01-0401) ("[T]his Court should enter a declaratory judgment ... striking the [make-up] policy as violating federal law, and enjoining Defendant from enforcing that policy.").

216. See Case, supra note 28, at 1365 ("This was a settlement Jespersen herself was offered but declined to take, in part because she did not see herself as exceptional in objecting to the makeup requirement, only in her willingness to sue, and she did not want to be 'singled ... out in a problematic way' from her female coworkers."). 
relief they seek is to eliminate the sex classification itself. Transgender plaintiffs, by contrast, accept sex-based rules and simply seek access to them on the basis of their identified sex. ${ }^{217}$ As one court has recognized, not only do transgender plaintiffs not unsettle sex-based rules, they sometimes reinforce them. ${ }^{218}$ This means that judges granting relief in transgender cases do not have to worry about upsetting remaining areas of generally accepted sex-based classifications, like bathrooms and grooming. Nor do judges have to worry about unduly interfering with the leeway the law typically affords employers and other regulated entities in running their institutions. One court addressing a challenge to a sex discriminatory dress code candidly explained its concerns:

[I]f it be mandated that men must be allowed to wear shoulder length hair... because the employer allows women to wear hair that length, then it must logically follow that men, if they choose, could not be prevented by the employer from wearing dresses to work if the employer permitted women to wear dresses.... [I]t would not be at all illogical to include lipstick ... and other items of typical female attire among the items which an employer would be powerless to restrict to female attire.... It would be patently ridiculous to presume that Congress ever intended such result....219

By providing relief in more palatable transgender plaintiff cases rather than in the less palatable cisgender plaintiff cases, judges can give effect to the gender nonconformity doctrine without pressing it too far in ways that upset social norms or business judgment. To be clear, I do not mean here to legitimate sex-based dress codes or other sex-based rules, many of which scholars, including myself, have roundly criticized. ${ }^{220}$ I simply mean to highlight the ways in which it is relatively easier for courts to accept transgender plaintiffs as gender nonconformers than cisgender plaintiffs, and how this can undermine cisgender plaintiffs' claims. And note, of course, that any weakening of cisgender plaintiffs' claims would tend to solidify these sex-based

217. See, e.g., Bostock v. Clayton Cnty., 140 S. Ct. 1731, 1738 (2020) ("Ms. Stephens wrote a letter to her employer explaining that she planned to live and work full-time as a woman.'”).

218. Whitaker v. Kenosha Unified Sch. Dist. No. 1 Bd. of Educ., 858 F.3d 1034, 1055 (7th Cir. 2017) ("Although the School District argues that implementing an inclusive policy will result in the demise of gender-segregated facilities in schools, the amici ... have found that allowing transgender students to use facilities that align with their gender identity has actually reinforced the concept of separate facilities for boys and girls.").

219. Willingham v. Macon Tel. Publ'g Co., 352 F. Supp. 1018, 1020 (M.D. Ga. 1972), rev'd, 482 F.2d 535 (5th Cir. 1973), vacated en banc, 507 F.2d 1084 (5th Cir. 1975); see also Case, supra note 14, at 62-63 (quoting and discussing Willingham).

220. See Schoenbaum, supra note 32; infra notes 289-91 and accompanying text. 
rules, as it is the cisgender plaintiffs who have tended to challenge them.

Finally, wrongly treating transgender and cisgender cases under the same doctrine can sow judicial confusion. The harms that transgender persons experience are all harms that flow from not being afforded the opportunity to conform their gender to their identified sex. Conversely, the harms that cisgender persons experience are all harms that flow from not being afforded the opportunity not to conform their gender to their identified sex. This puts courts in the confusing position of comparing cases that are addressing two very different types of harms. We can see one court that has already admitted confusion flowing from the two very different types of claims being pursued under the same theory. ${ }^{221}$

The impact may extend beyond confusion, to undermining protection for gender nonconformity. In transgender cases, judges hear evidence about the importance of gender conformity-the importance of conforming the transgender plaintiff's gender presentation to their identified sex.222 And, indeed, gender conformity may have unique and understandable value for transgender persons.223 This need for gender conformity may be more relatable and persuasive to judges staffing the federal bench than the need for gender nonconformity sought by cisgender plaintiffs. ${ }^{224}$ However, by treating

221. Harris I, 201 F. Supp. 3d 837, 861 (E.D. Mich. 2016) ("The only reason that the EEOC can pursue a Title VII claim on behalf of Stephens in this case is under the theory that the Funeral Home discriminated against Stephens because Stephens failed to conform to the 'masculine gender stereotypes that [the employer] expected' in terms of the clothing Stephens would wear at work.... Rather than challenge the [Funeral Home's] sex-specific dress code, the EEOC takes the position that Stephens has the right, under Title VII, to 'dress as a woman' or wear 'female clothing' while working at the Funeral Home... . to be permitted to dress in a stereotypical feminine manner." (footnote omitted)).

222. Yuracko, supra note 14, at 799-801 (collecting cases in which transgender plaintiffs rely on medical evidence to establish the psychological need to conform their gender to their identified sex).

223. See, e.g., Bostock v. Clayton Cnty., 140 S. Ct. 1731, 1738 (2020) ("When she got the job, Ms. Stephens presented as a male. But two years into her service with the company, she began treatment for despair and loneliness. Ultimately, clinicians diagnosed her with gender dysphoria and recommended that she begin living as a woman.").

224. In a dissenting opinion, then-Judge Kozinski highlights how at the heart of the loss in Jespersen was his fellow judges not relating to and therefore not crediting the harm that stems from enforced gender conformity:

Jespersen did introduce evidence that she finds it burdensome to wear makeup because doing so is inconsistent with her self-image and interferes with her job performance. My colleagues dismiss this evidence, apparently on the ground that wearing makeup does not, as a matter of law, constitute a 
cisgender plaintiffs under the same doctrine, judges may fail to recognize just how important gender nonconformity is to some cisgender persons, undermining cisgender plaintiffs' claims and in turn the law's protection for gender nonconformity.

The preceding Part has traced how, notwithstanding the relief it has provided to transgender persons, the gender nonconformity doctrine as applied to transgender discrimination has caused harm, by compelling losses, by generating Pyrrhic victories, and by undermining cisgender plaintiffs' claims. We might think that the substantial benefits of applying the gender nonconformity doctrine in this context outweigh its costs, but the next Part will explain why this isn't so: the costs are not necessary because transgender plaintiffs can gain relief without such costs.

\section{TRANSGENDER DISCRIMINATION AS SEX DISCRIMINATION}

The harms associated with the gender nonconformity doctrine are unnecessary. This is because transgender discrimination can be recognized as sex discrimination without resort to the gender nonconformity doctrine. ${ }^{225}$ Rather, transgender discrimination can be considered sex discrimination under a textual analysis of a ban on sex discrimination. ${ }^{226}$ This is because, as Bostock holds, a decision maker cannot act on the basis of transgender status without acting on the basis of sex.227 This theory corrects the error at the heart of treating transgender discrimination cases as gender nonconformity cases: understanding transgender status as a matter of gender rather than sex.

But while Bostock avoids the main pitfall and the associated harms of the gender nonconformity doctrine, it introduces its own problem. In applying a thin textual analysis of transgender discrimination as sex discrimination, it fails to connect the social phenomenon

substantial burden.... If you are used to wearing makeup-as most American women are-this may seem like no big deal. But those of us not used to wearing makeup would find a requirement that we do so highly intrusive. Imagine, for example, a rule that all judges wear face powder, blush, mascara and lipstick while on the bench. Like Jespersen, I would find such a regime burdensome and demeaning; it would interfere with my job performance. I suspect many of my colleagues would feel the same way.

Jespersen v. Harrah's Operating Co., 444 F.3d 1104, 1117-18 (Kozinski, Graber, \& Fletcher, JJ., dissenting) (citation omitted).

225. Bostock, $140 \mathrm{~S}$. Ct. at 1739-41 (relying on a textual but-for causation analysis to find sex discrimination).

226. $I d$.

227. Id. 
of transgender discrimination to the social phenomenon of sex discrimination, and instead suggests that the two phenomena are distinct. In so doing, the decision fails to elucidate how transgender plaintiffs further the anti-stereotyping aims of sex discrimination law, treating these plaintiffs as marginal cases rather than part of the core. This can cause harm legally, when transgender rights claims are pitted against religious liberty defenses, and socially, when solidarity is sought between transgender rights and women's rights.

But this shortcoming of Bostock can be fixed. Transgender persons do fight sex stereotypes in the way sex discrimination law has long sought to do, because they face discrimination that is motivated by the same sex stereotypes that have long held women and men back on the basis of sex. Going forward, courts and commentators should elucidate how this is so.

This Section proceeds in two parts. It first lays out what Bostock gets right, discussing how the decision comes to hold that transgender discrimination is sex discrimination, and how it corrects the shortcomings of the gender nonconformity doctrine. Next, it addresses how, notwithstanding the advance that Bostock represents, the decision's approach falls short by setting transgender discrimination apart from sex discrimination, why this matters, and how it can be fixed.

\section{A. What Bostock Gets Right: The Doctrine of Transgender DisCRIMINATION AS SEX DisCRIMINATION}

Before Bostock, scholars advocated a turn to textualism to interpret bans on discrimination "because of ... sex"228 to apply to transgender discrimination. ${ }^{229}$ The textualist approach recognizes that a regulated entity cannot discriminate on the basis of transgender status without taking into account a transgender person's birth-designated sex, and thus transgender status discrimination is necessarily sex discrimination. ${ }^{230}$

228. See, e.g., 42 U.S.C. § 2000e-2(a)(1).

229. See, e.g., Katie R. Eyer, Statutory Originalism and LGBT Rights, 54 WAKE FOREST L. REv. 63 (2019) (advocating a textualist approach to Title VII that would read the ban on sex discrimination to extend to transgender discrimination and arguing against a statutory originalism argument, i.e., that the original public meaning of the statute did not contemplate such coverage); Young, supra note 14, at 15 ("Under a strict textualist approach, the question of whether Title VII protects transgender people can be easily answered in the affirmative.").

230. To spell it out, assume an employer or other regulated entity discriminates against someone for being transgender-that is, for a transgender woman, having a male sex assigned at birth and desiring to or actually living openly as a woman, or, for 
This is essentially the approach that Bostock takes. The heart of the analysis is quite "simple":

An individual's ... transgender status is not relevant to employment decisions. That's because it is impossible to discriminate against a person for being ... transgender without discriminating against that individual based on sex.... [T] ake an employer who fires a transgender person who was identified as a male at birth but who now identifies as a female. If the employer retains an otherwise identical employee who was identified as female at birth, the employer intentionally penalizes a person identified as male at birth for traits or actions that it tolerates in an employee identified as female at birth.... [T] he individual employee's sex plays an unmistakable and impermissible role in the discharge decision. ${ }^{231}$

In other words, if an employer treats an employee who was designated male at birth and now identifies as female differently than an employee who was designated female at birth and now identifies as female, that is discrimination because of sex.

The remainder of the legal analysis in the thirty-seven page opinion ${ }^{232}$ is spent on explicating the causation standard (i.e., what it means to discriminate "because of ... sex"), ${ }^{233}$ defining discrimination (i.e., whether the focus is on individuals or groups), ${ }^{234}$ discussing precedents, ${ }^{235}$ and rebutting counterarguments. ${ }^{236}$ Quite notably, after the lower courts' near universal reliance on the gender nonconformity

a transgender man, having a female sex assigned at birth and desiring to or actually living openly as a man. The discrimination would not have occurred but for the transgender woman being assigned the female sex at birth or but for the transgender man being assigned the male sex at birth. That is sex discrimination. 42 U.S.C. § 2000e2(a)(1) (prohibiting employers from discriminating "because of" sex); L.A. Dep't of Water \& Power v. Manhart, 435 U.S. 702 (1978) (holding that when the same decision would not have been made had the employee's sex been different, an employer discriminates "because of sex").

231. Bostock, $140 \mathrm{~S}$. Ct. at 1741-42.

232. Bostock v. Clayton Cnty., No. 17-1618, slip op. (June 15, 2020), https://www .supremecourt.gov/opinions/19pdf/17-1618_hfci.pdf [https://perma.cc/T8Q4 -HNMN].

233. Bostock, 140 S. Ct. at 1739 ('The question isn't just what 'sex' meant, but what Title VII says about it. Most notably, the statute prohibits employers from taking certain actions 'because of' sex.").

234. Id. at 1740 (" $[\mathrm{H}]$ ow can we tell which sense, individual or group, 'discriminate' carries in Title VII?").

235. Id. at 1743 ("If more support for our conclusion were required, there's no need to look far.... Consider three of our leading precedents.").

236. Id. at 1744. Although there are a number, one of the most important is the Court's recognition that Title VII's "broad" text barring sex discrimination governs regardless of whether it might have "unanticipated" and "wide-ranging" consequences. Id. at 1752 (citing Franklin, supra note 66, at 1340, 1345). 
doctrine to recognize transgender rights under Title VII, 237 there is no mention of the doctrine.

Bostock's textual approach to treating transgender discrimination as sex discrimination has both benefits and costs. First, and most importantly for purposes of this Article, this theory of transgender discrimination as sex discrimination avoids the substantial shortcomings of the gender nonconformity doctrine. By referring to a transgender woman as a person who was "identified as a male at birth" but who now "identifies as a female,"238 Bostock gets one thing exactly right that the gender nonconformity doctrine gets exactly wrong: that being transgender is about changing one's designated sex, not about changing one's gender. ${ }^{239}$ Significantly, the opinion uses female pronouns to refer to Aimee Stephens, at a minimum recognizing that she identified as a woman. ${ }^{240}$ The decision even avoids indicating that Stephens was ever a man. ${ }^{241}$ Critically, then, this theory of discrimination does not rely on a fixed notion of sex designated at birth. ${ }^{242}$ The decision avoids the thorny issue of defining what sex means altogether. ${ }^{243}$

The Court's recognition that transgender persons are seeking to change their designated sex rather than their gender is an enormous

237. See supra notes 114-19 and accompanying text.

238. Bostock, 140 S. Ct. at 1741.

239. As I discussed earlier, it is not always. Some transgender persons view this as gender rather than sex. See supra note 6. But Bostock should apply anyway. See infra notes 258-60 and accompanying text.

240. Bostock, 140 S. Ct. at 1738 ("When she got the job, Ms. Stephens presented as a male.").

241. Justice Gorsuch recounts only that "[w]hen she got the job, Ms. Stephens presented as a male," that "[u]ltimately, clinicians diagnosed her with gender dysphoria and recommended that she begin living as a woman," and that "[i]n her sixth year with the company, Ms. Stephens wrote a letter to her employer explaining that she planned to 'live and work full-time as a woman' ...." Id. at 1738.

242. See supra notes 16-20. The Court punts on questions of what the decision means for sex classification cases, stating that "none of these other laws are before us; we have not had the benefit of adversarial testing about the meaning of their terms, and we do not prejudge any such question today.... [W] do not purport to address bathrooms, locker rooms, or anything else of the kind." See Bostock, 140 S. Ct. at 1753.

243. Justice Gorsuch acknowledges that the parties dispute the meaning of the term "sex," but concludes that "because nothing in our approach to these cases turns on the outcome of the parties' debate, and because the employees concede the point for argument's sake, we proceed on the assumption that 'sex' signified what the employers suggest, referring only to biological distinctions between male and female." Bostock, $140 \mathrm{~S}$. Ct. at 1739 . Note that the Court probably should have relied on birthdesignated sex, as no one is actually checking the biological features of plaintiffs in assessing their sex. 
advance over the retrograde notions of transgender persons' sex under the gender nonconformity doctrine. Regardless of whether this theory is applied in gender performance cases or sex classification cases, it will not undermine transgender plaintiffs' claims in sex classification cases, and instead will further them. And because it avoids the gender nonconformity theory, it will not confuse courts in cases where transgender plaintiffs seek access to sex classifications or undermine the claims of gender nonconformers. ${ }^{244}$

And this approach offers broader protection than the gender nonconformity theory, as it would apply before any gender nonconforming behavior takes place. It would also apply regardless of whether the decision maker discriminates against the transgender person for gender nonconformity and regardless of whether the decision maker even perceives the transgender person to be gender nonconforming. As scholars have acknowledged, the root of bias against transgender persons is more likely to be bias against being transgender itself (i.e., against changing designated sex) than gender nonconforming behavior. ${ }^{245}$ Bostock's theory of sex discrimination captures this, providing a more descriptively accurate account of transgender discrimination, while making it easier for transgender plaintiffs to prove their claims.

This theory of sex discrimination is also superior to a "regarded as" theory of gender nonconformity, which would focus on the decision maker's motive-i.e., whether the transgender person was perceived as gender nonconforming-rather than on whether the transgender person is in fact gender nonconforming. ${ }^{246}$ Proceeding on a "regarded as" gender nonconformity theory requires proof of this particular motive on the part of the decision maker. ${ }^{247}$ This motive may or may not have been present, and, even when it was, it may be difficult to prove. ${ }^{248}$ Moreover, applying the "regarded as" gender nonconformity theory may continue to problematically reinforce the

244. Cf. supra notes 203-19 and accompanying text (describing courts' troubles applying gender nonconformity theory).

245. See Kirkland, supra note 6, at 30 ("Actually pursuing an existence in a sex category other than the one genitally assigned at birth horrifies people in ways that effeminate men (as horrifying as they are) do not... It is not clear that the Price Waterhouse sex stereotyping theory addresses this fact at its roots."); Lee, supra note 156, at 446 (noting that transgender discrimination is far more likely to be on the basis of transgender identity than gender nonconformity).

246. See supra notes 154-55 and accompanying text.

247. See Ulane v. E. Airlines, 742 F.2d 1081, 1087 (7th Cir. 1984) (holding that the transgender plaintiff designated male at birth could not claim sex discrimination on the basis of being a woman because the employer did not regard her as such).

248. Id. 
notion that being transgender is about gender rather than sex, just as the gender nonconformity theory itself does.

Note that the approach to treating transgender discrimination as sex discrimination adopted by Bostock doesn't guarantee victory for transgender persons who seek access to sex-segregated spaces or sexbased rules, like bathrooms and dress codes, based on their identified sex. The Court determined that Stephens's termination was due to her transgender status rather than her failure to comply with the dress code, so it did not address this question. 249

While it does not resolve the issue, the Bostock approach does set up transgender plaintiffs to prevail in sex classification cases. They could do so in one of two ways. Stephens and some amici argued that denying a transgender woman like her access to the women's dress code or women's bathroom is a form of actionable sex discrimination under Title VII. ${ }^{250}$ These forms of sex segregation clearly result in sexbased action, so there is no question that any such actions are "because of sex." The only question is whether such actions "discriminate" in the way that the law prohibits, ${ }^{251}$ that is, whether transgender (or cisgender) employees are sufficiently harmed by the sex-based rules for a violation to result.252 In such cases, individual exceptions to sex-based rules would be appropriate. ${ }^{253}$

249. See supra note 18.

250. See, e.g., Brief of Professors Samuel R. Bagenstos, Michael C. Dorf, Martin S. Lederman, Leah M. Litman, and Margo Schlanger as Amici Curiae in Support of Respondent Stephens at 15-18, Harris III, 139 S. Ct. 1599 (2019) (mem.) (No. 18-107), 2019 WL 2915048, at *16-18 [hereinafter Brief of Professors]; Brief for Respondent Aimee Stephens, supra note 11, at 50-52.

251. 42 U.S.C. $§ 2000 \mathrm{e}-2$ (a)(1) (barring covered employers from "discriminat[ing]" with respect to the "terms" or "conditions" of an individual's employment); § 2000e2(a)(2) (barring covered employers from "segregat[ing] or classify[ing] ... employees" on the basis of their sex when doing so would "deprive or tend to deprive any individual of employment opportunities or otherwise adversely affect his status as an employee").

252. That is, whether the sex-based rule is sufficiently burdensome that it affects the "terms" or "conditions" of employment, 42 U.S.C. $§ 2000 \mathrm{e}-2$ (a)(1), or "deprive[s] or tend[s] to deprive" employees of "employment opportunities" or "otherwise adversely affect" them as employees, id. § 2000e-2(a)(2). See Brief for Respondent Aimee Stephens, supra note 11, at 51 ("[Employer] suggests that forbidding employers from discharging employees because they are transgender would somehow automatically invalidate all sex-specific rules. But that is not true.... The existence of separate restrooms for men and women, for example, would violate Title VII only if an individual employee could show that the restrooms adversely affected a term or condition of the employee's employment." (citation omitted)).

253. Brief of Professors, supra note 250, at 16 ("Where [sex-based] rules impose little burden on employees, they will not constitute forbidden discrimination even though they are plainly based upon-imposed 'because of' - the sex of the employees 
An alternative approach would not rely on exceptions. The claim would simply be that sex-based rules differentiate between persons who are legally female and persons who are legally male. A transgender woman is legally a woman and a transgender man is legally a man, and thus they are entitled to use the bathrooms and dress codes associated with that sex. The question of a person's legal sex has been treated as a matter of state law, even when pressed as part of a federal lawsuit. ${ }^{254}$ And under a large and growing number of state laws, transgender persons' identified sex is their legal sex. ${ }^{255}$ Regardless of how sex classification cases proceed, the approach of the Bostock court tees up transgender plaintiffs to prevail in these claims, by treating transgender status for what it is: a matter of sex rather than gender.

While the Bostock approach to transgender discrimination marks a huge advance over the gender nonconformity theory, it is not clear that Bostock marks the fall of the new law of gender nonconformity, for a few reasons. First, there are countless laws at the federal, state, and local level that bar sex discrimination. ${ }^{256}$ The Court's interpretation of Title VII of course does not control the interpretation of these other laws. But there is reason to believe that it will, as the Supreme Court's approach to sex discrimination under Title VII has tended to migrate to lower federal and state courts' interpretations of what counts as sex discrimination under other laws. ${ }^{257}$ Second, in Title VII cases or others, transgender plaintiffs may either explicitly raise the

in question. [It] is therefore incorrect to suggest that a ruling for Stephens would lead to the wholesale invalidation of reasonable, sex-based workplace standards." (citation omitted)).

254. See, e.g., Radtke v. Misc. Drivers \& Helpers Union Loc.l 638, 867 F. Supp. 2d 1023 (D. Minn. 2012) (evaluating an individual's sex as a matter of state law in assessing a claim under federal employment law (ERISA) that turns on that individual's sex).

255. See supra notes 181-83 and accompanying text.

256. To name just a few, there is the Equal Protection Clause of the U.S. Constitution, U.S. ConST. amend. XIV, $\S 1$, and Title IX of the Education Amendments of 1972, 20 U.S.C. § 1681(a). See Bostock v. Clayton Cnty., 140 S. Ct. 1731, 1778 (2020) (Alito \& Thomas, JJ., dissenting) ("Over 100 federal statutes prohibit discrimination because of sex.").

257. See, e.g., Whitaker v. Kenosha Unified Sch. Dist. No. 1 Bd. of Educ., 858 F.3d 1034 (7th Cir. 2017) (relying on Price Waterhouse to interpret the meaning of sex discrimination in a Title IX case); Back v. Hastings on Hudson Union Free Sch. Dist., 365 F.3d 107 (2d Cir. 2004) (relying on Price Waterhouse to find sex discrimination in an equal protection case). Justice Alito's dissent recognizes the potential reach of the decision. See Bostock, 140 S. Ct. at 1778 (Alito \& Thomas, JJ., dissenting) (noting that the majority's decision "is virtually certain to have far-reaching consequences" in light of the many federal laws barring sex discrimination). 
gender nonconformity doctrine or implicitly frame their claims in those terms, and courts may then analyze the case accordingly.

It might make sense to continue to rely on the gender nonconformity doctrine in cases where transgender persons do not seek to change their designated sex. While the vast majority of transgender plaintiffs in litigated cases have sought to change the sex they were designated at birth, not all persons who identify as transgender do. ${ }^{258}$ Transgender status incorporates a range of identities with various relationships between sex and gender, including those who want to retain the sex they were designated at birth while shifting their gender presentation. ${ }^{259}$ While these persons self-identify as transgender, the relationship between their sex and their gender is more similar to that of traditional gender nonconformers. They retain their designated sex, but do not conform their gender to it. For this reason, these persons could choose to proceed on the Bostock approach or the gender nonconformity approach. ${ }^{260}$ Which approach they take may depend on the motive for discrimination in their case.

Importantly, whenever the gender nonconformity doctrine is invoked in cases with transgender plaintiffs, it should be adjusted to avoid the problems with the doctrine that are the subject of this Article. Instead of operating under a per se assumption about the relationship between sex and gender across transgender persons, courts should ground their gender nonconformity analysis in a "regarded as" theory of discrimination based on the discriminatory motive involved in the case. This is both more faithful to the terms of sex discrimination law and more accurate as a matter of fact.

While courts have not universally accepted the "regarded as" theory of discrimination, they should.261 Disparate treatment

258. See supra note 6 .

259. See GLAAD MEDIA REFERENCE GuIDE, supra note 6, at 10-11; $c f$. Dylan Vade, Expanding Gender and Expanding the Law: Toward a Social and Legal Conceptualization of Gender That Is More Inclusive of Transgender People, 11 MICH. J. GENDER \& L. 253, 260 (2005) ("[T] here are many transgender people who do not identify as either female or male, but as a third or other gender, such [as] trans or boy-girl, just to name a few."); Jessica A. Clarke, They, Them, and Theirs, 132 HARV. L. REV. 894, 905-10 (2019) (discussing the range of nonbinary gender identity).

260. Under the Bostock approach, taking an adverse action would be due to sex if the employer harms a person identified as male at birth who adopts a feminine gender presentation (while still identifying as male) but does not visit that same harm upon a person identified as female at birth who adopts a feminine gender presentation. See Bostock, 140 S. Ct. at 1741-42.

261. Title VII does not contain a "regarded as" provision like the Americans with Disabilities Act (ADA) does. 42 U.S.C. § 12102(1)(C) (defining what counts as a "disability," including "being regarded as having" certain impairments). But that is not 
discrimination is a matter of the regulated decision maker's intent. What matters are not any objective facts about the target of the discrimination; what matters is the decision maker's discriminatory motive. Therefore, if a decision maker discriminates against someone because the decision maker perceives that person to fail to conform their gender to their sex, this is sex discrimination, regardless of the reality. The Supreme Court said as much in Price Waterhouse:

It is not our job to review the evidence and decide that the negative reactions to Hopkins were based on reality; our perception of Hopkins' character is irrelevant. We sit not to determine whether Ms. Hopkins is nice, but to decide whether the partners reacted negatively to her personality because she is a woman. ${ }^{262}$

This approach allows courts to avoid hard inquiries assessing objective gender nonconformity, which would require courts to engage in the distasteful and counterproductive project of defining gender conforming behavior and assessing deviation from it.

Second, as a matter of fact, there is no necessary or per se relationship between sex and gender that motivates discrimination against transgender plaintiffs. It is not the case that a transgender person who was designated male at birth and has a feminine gender presentation would necessarily be perceived as an insufficiently masculine man. This person may be perceived not as an "insufficiently masculine man," but as an "insufficiently feminine woman." 263 We can see precisely this in a case where the employer was concerned not that the transgender female employee was an excessively feminine man but rather an excessively masculine woman. ${ }^{264}$ In that case, the court got it right when it said that it would be gender nonconformity discrimination regardless of whether the employer perceived the plaintiff to be "an insufficiently masculine man" or "an insufficiently feminine woman." 265

dispositive in the least, because these are very different statutes. The ADA is an asymmetrical law with a defined protected class, and thus persons who are covered by the law must be expressly included. See id. Title VII is a symmetrical law without a defined protected class, and thus there is no need to expressly include anyone within its reach. Id. § $2000 \mathrm{e}-2$ (barring discrimination on the basis of "race, color, religion, sex, or national origin" without defining these groups). See generally Naomi Schoenbaum, The Case for Symmetry in Antidiscrimination Law, 2017 WIS. L. REv. 69 (discussing symmetry and asymmetry as a design choice in antidiscrimination law).

262. Price Waterhouse v. Hopkins, 490 U.S. 228, 258 (1989) (plurality opinion).

263. Schroer v. Billington, 577 F. Supp. 2d 293, 305 (D.D.C. 2008).

264. Id. ("[The employer]'s credibility concern was that [plaintiff] 'would not be deemed credible by Members of Congress and their staff because people would perceive her to be a woman, and would refuse to believe that she could possibly have the [military] credentials that she had.'”).

265. Id. at 305 . 
Even if the Bostock approach is adopted broadly across sex discrimination law, it is not perfect. Bostock fails to connect transgender discrimination to other forms of sex discrimination, suggesting that the two are distinct. The next Section takes up this shortfall, why it matters, and what to do about it.

\section{B. What Bostock Misses: The Theory of Transgender Discrimination AS SEX DisCRimination}

By hewing to statutory text and avoiding theories of sex discrimination, Bostock introduces a new problem: it is silent on how transgender discrimination fits within the social phenomenon of sex discrimination, and even goes so far as to suggest that it does not. The decision thus fails to show how combatting transgender discrimination furthers the key goals of sex discrimination law. This Section first discusses how Bostock sets transgender discrimination apart from sex discrimination. It then explains why this matters, legally and socially. Finally, it suggests how courts might fix this shortcoming.

Bostock sets transgender discrimination apart from sex discrimination as a social and legal phenomenon both by what it says and by what it doesn't say. What the decision does not say is more telling than what it does, so that is the appropriate place to begin. Perhaps the most revealing analysis is to contrast the Bostock opinion with other key Title VII sex discrimination victories in the Court's history. In these cases, the Court focused on how sex discrimination plays out on the ground as a social phenomenon, relying on sociological realities and psychological theories in doing so. ${ }^{266}$ In Price Waterhouse v. Hopkins, for example, the Court relied on the psychological theory of sex

\footnotetext{
266. See, e.g., Meritor Sav. Bank, FSB v. Vinson, 477 U.S. 57, 67, 72-73 (1986) (recognizing a cause of action for sexual harassment without an economic consequence, and noting that "[s] exual harassment which creates a hostile or offensive environment for members of one sex is every bit the arbitrary barrier to sexual equality at the workplace that racial harassment is to racial equality" because "[s]urely, a requirement that a man or woman run a gauntlet of sexual abuse in return for the privilege of being allowed to work and make a living can be as demeaning and disconcerting as the harshest of racial epithets," and relying on the facts of the case to show the real world inadequacy of the position "that the mere existence of a grievance procedure and a policy against discrimination, coupled with [the employee]'s failure to invoke that procedure, must insulate [the employer] from liability" because the employer's "nondiscrimination policy did not address sexual harassment in particular, and thus did not alert employees to their employer's interest in correcting that form of discrimination," and because "the [employer]'s grievance procedure apparently required an employee to complain first to her supervisor," and here the supervisor "was the alleged perpetrator," and thus "it is not altogether surprising that [the employee] failed to invoke the procedure and report her grievance to him").
} 
stereotyping to understand how discrimination operates against women in the workplace. ${ }^{267}$ And the Court explained how this occurs: "An employer who objects to aggressiveness in women but whose positions require this trait places women in an intolerable and impermissible catch 22: out of a job if they behave aggressively and out of a job if they do not. Title VII lifts women out of this bind."268 Finally, the Court goes on to describe why the evidence should be interpreted as action on the basis of sex:269 "It takes no special training to discern sex stereotyping in a description of an aggressive female employee as requiring 'a course at charm school."'270 And "if an employee's flawed 'interpersonal skills' can be corrected by a soft-hued suit or a new shade of lipstick, perhaps it is the employee's sex and not her interpersonal skills that has drawn the criticism." 271

In Bostock, by contrast, there is no discussion of the theory or reality of how transgender discrimination amounts to sex discrimination. The majority opinion relies entirely on hypotheticals to illustrate its legal point that transgender discrimination is sex discrimination. ${ }^{272}$ It does not reference any theoretical or empirical research about how transgender discrimination operates. ${ }^{273}$ Nor does it address how the discrimination in the cases before it actually played out. 274

This void is notable given that Justice Kavanaugh's dissent does take on the historical and sociological place of LGBTQ rights, making the argument that they are separate and apart from women's rights: “Seneca Falls was not Stonewall... The women's rights movement was not (and is not) the gay rights movement, although many people obviously support or participate in both. So to think that sexual orientation discrimination is just a form of sex discrimination is not just a

\footnotetext{
267. 490 U.S. at $250-51$.

268. Id. at 251.

269. Given the expert evidence of sex stereotyping as sex discrimination that the Court held was properly relied on below, the Court did not need to explain how the stereotyping evidence amounted to evidence of sex discrimination, but it did so nonetheless. See id. at 255.

270. Id. at 256 .

271. Id.

272. See, e.g., Bostock v. Clayton Cnty., 140 S. Ct. 1731, 1741 (2020) ("Consider, for example, an employer with two employees, both of whom are attracted to men.... Or take an employer who fires a transgender person who was identified as a male at birth but who now identifies as a female.").

273. See id.

274. See id.
} 
mistake of language and psychology, but also a mistake of history and sociology." 275 The majority says nothing in response. 276

As for what is there, the opinion suggests that transgender discrimination is a separate social phenomenon from what is commonly thought of as sex discrimination, including sex stereotyping, with different motivations and consequences. Take this passage, which rebuts the employer's argument that a stricter causation standard should apply to sex discrimination claims on the basis of transgender status (or sexual orientation) than to other sex discrimination claims:

Such a rule would create a curious discontinuity in our case law, to put it mildly. Employer hires based on sexual stereotypes? Simple test. Employer sets pension contributions based on sex? Simple test. Employer fires men who do not behave in a sufficiently masculine way around the office? Simple test. But when that same employer discriminates against ... persons identified at birth as women who later identify as men, we suddenly roll out a new and more rigorous standard?277

This intimates that when employers discriminate against transgender persons, they are not at the same time acting on "sexual stereotypes" or against "men who do not behave in a sufficiently masculine way around the office." 278 In other words, transgender discrimination is its own separate social practice that is not motivated by the same sex stereotypes that have long been recognized to motivate other forms of sex discrimination.

Or consider the Court's approach to addressing the employer's argument that the legislature's "failure to speak directly to a specific case that falls within a more general statutory rule creates a tacit exception." 279 The Court makes the fair concession that "homosexuality and transgender status are distinct concepts from sex." 280 In holding that Title VII's sex discrimination ban covers discrimination on these additional bases as well, the Court says that "discrimination based on homosexuality or transgender status necessarily entails discrimination based on sex; the first cannot happen without the second."281 This was an opportunity for the Court to draw parallels between transgender discrimination and other forms of discrimination that occur on the basis of sex. The court declined to do so. Instead, the opinion draws parallels to Oncale v. Sundowner Offshore Services, Inc.,

275. Id. at 1828-29 (Kavanaugh, J., dissenting).

276. See id. at 1734-54.

277. Id. at 1749 .

278. Id.

279. Id. at 1747 .

280. Id. at $1746-47$.

281. Id. at 1747 . 
where the Court held that male-on-male harassment may constitute unlawful sexual harassment, even if this type of discrimination was not "the principal evil Congress was concerned with when it enacted Title VII."282 The thrust of the decision thus underscores how transgender discrimination is separate from and different than more well-recognized forms of sex discrimination.

Bostock's failure to make transgender rights a central piece of sex discrimination's core anti-stereotyping aim-and indeed to suggest the opposite-matters both legally and socially. Legally, this shortcoming becomes relevant when transgender rights claims are tested against religious exemption defenses. The Religious Freedom Restoration Act (RFRA) bars the application of neutral laws that unduly burden religious practice or belief. ${ }^{283}$ Under RFRA, "Government shall not substantially burden a person's exercise of religion even if the burden results from a rule of general applicability," unless the Government "demonstrates that application of the burden to the person-(1) is in furtherance of a compelling governmental interest; and (2) is the least restrictive means of furthering that compelling governmental interest." 284 In the district and appellate court, Stephens's employer, a funeral home, pressed a RFRA defense to her sex discrimination claim. ${ }^{285}$

Looking at the Sixth Circuit's decision rejecting the defense, RFRA might not seem like a huge hurdle to overcome in transgender discrimination cases. There, the court, relying on dicta from a $2014 \mathrm{Su}-$ preme Court decision, stated that "enforcement actions brought under Title VII ... will necessarily defeat RFRA defenses to discrimination made illegal by Title VII."286 But Bostock invited RFRA claims as a way

282. 523 U.S. 75, 79 (1998).

283. See 42 U.S.C. $\S 2000$ bb-1; Burwell v. Hobby Lobby Stores, 573 U.S. 682 (2014).

284. 42 U.S.C. $\S \S 2000$ bb-1(a) to -1(b); see also Hobby Lobby, 573 U.S. at 682 (holding that RFRA applies to the activities of closely held for-profit corporations, and therefore such corporations cannot be required to facilitate access to contraceptives that violate their sincere religious beliefs). Many states have their own analogues. State Religious Freedom Restoration Acts, NAT'L CONF. ST. LEGISLATURES (May 4, 2017), https:// www.ncsl.org/research/civil-and-criminal-justice/state-rfra-statutes.aspx [https:// perma.cc/WS4B-F2C6] (citing twenty-one states).

285. See Harris I, 201 F. Supp. 3d 837, 863 (E.D. Mich. 2016) (upholding the defense); Harris II, 884 F.3d 560, 595-97 (6th Cir. 2018) (rejecting the defense).

286. Harris II, 884 F.3d at 595. In Burwell v. Hobby Lobby Stores, Inc., which upheld an employer's objection to the Affordable Care Act's contraception mandate under RFRA, the Court addressed the dissent's concern "that discrimination in hiring, for example on the basis of race, might be cloaked as religious practice to escape legal sanction." 573 U.S. at 733 (citation omitted). The Court responded that RFRA "provides no such shield" because "[t]he Government has a compelling interest in providing an 
to manage the decision's imposition on religion. ${ }^{287}$ And the Court's increasing deference to claims of religious liberty when weighed against antidiscrimination rights might raise some alarm bells. ${ }^{288}$ Indeed, some of the commentary on Bostock has to do with the way the Court's religious freedom jurisprudence will limit the rights granted in the case: what rights the Court giveth in Bostock, it has (or will) taketh away through granting religious exemptions. ${ }^{289}$ So while Justices

equal opportunity to participate in the workforce without regard to race, and prohibitions on racial discrimination are precisely tailored to achieve that critical goal." Id. Note that the Court's suggestion that Title VII might be invulnerable to RFRA defenses was with regard to race discrimination rather than sex discrimination. And courts have applied the RFRA defense in employment discrimination cases. See, e.g., Hankins v. Lyght, 441 F.3d 96, 109 (2d Cir. 2006) (allowing RFRA defense in federal age employment discrimination lawsuit). Finally, while the government (the EEOC) pursued Stephens's claim in Bostock, there is a question of whether RFRA applies between private parties. Compare Listecki v. Off. Comm. of Unsecured Creditors, 780 F.3d 731, 738, 741 (7th Cir. 2015) (barring RFRA claim between private parties in a case under the bankruptcy code), with Hankins, 441 F.3d at 109 (allowing RFRA between private parties in federal age employment discrimination lawsuit). Even if RFRA is not available, First Amendment protection for religious freedom would be. Listecki, 780 F.3d at 741 (where RFRA is barred, applying First Amendment limits on government intrusion on religion through the application of federal law).

287. Bostock v. Clayton Cnty., 140 S. Ct. 1731, 1754 (2020). ("Because RFRA operates as a kind of super statute, displacing the normal operation of other federal laws, it might supersede Title VII's commands in appropriate cases."). Title VII itself has likewise been considered a "super statute," although the Court fails to mention this. William N. Eskridge Jr. \& John Ferejohn, Super-Statutes, 50 DukE L.J. 1215, 1237 (2001) (" $\mathrm{T}]$ he Civil Rights Act is a proven super-statute because it embodies a great principle (antidiscrimination), was adopted after an intense political struggle and normative debate and has over the years entrenched its norm into American public life, and has pervasively affected federal statutes and constitutional law.").

288. See, e.g., Our Lady of Guadalupe Sch. v. Morrissey-Berru, Nos. 19-267, 19-348, 2020 WL 3808420 (U.S. July 8, 2020) (exempting religious school teachers from application of employment discrimination law under a broad interpretation of the ministerial exemption); Masterpiece Cakeshop, Ltd. v. Colo. C.R. Comm'n, 138 S. Ct. 1719 (2018) (holding that requiring a baker to provide wedding services to a gay couple under state antidiscrimination law over the baker's religious objection would violate the right to the free exercise of religion); Hosanna-Tabor Evangelical Lutheran Church \& Sch. v. Equal Emp. Opportunity Comm'n., 132 S. Ct. 694 (2012) (holding that there is a ministerial exception to employment discrimination law grounded in the Religion Clauses of the First Amendment and applying it beyond the head of a religious congregation).

289. Linda Greenhouse, The Many Dimensions of the Chief Justice's Triumphant Term, N.Y. TIMES (July 16, 2020), https://www.nytimes.com/2020/07/16/opinion/ supreme-court-roberts-religion.html [https://perma.cc/NR3M-BF8J] [stating that "employers now can't fire someone for being gay or transgender, but we have yet to see the carve-outs that the religious right will demand and to which the court may well accede in subsequent cases" based on its concurrent expansion of religious rights); Leah Litman, Progressives' Supreme Court Victories Will Be Fleeting, ATLANTIC (July 14, 
Gorsuch and Roberts sided with transgender rights in Bostock, they seem poised to side with the claims of religious employers in future cases. ${ }^{290}$

Pitting transgender rights claims against RFRA defenses puts into stark relief the harmful impact of Bostock's separation of transgender rights from the core concerns of sex discrimination. We can see this in the district court's acceptance of a RFRA defense in Stephens's case. ${ }^{291}$ The court recognized the defense because it failed to appreciate how transgender plaintiffs achieve the core objectives of the law's ban on sex discrimination.

After assuming that the EEOC had a compelling interest in enforcing Title VII, ${ }^{292}$ the court assessed whether the government had

2020), https://www.theatlantic.com/ideas/archive/2020/07/court-gave -progressives-hollow-victories/614101 [https://perma.cc/5GSS-LWNM] ("[T] he

[Bostock] outcome was a major win for a progressive legal cause... [b] ut the reasoning in the decision suggests that victory will be limited in significant ways in the near future" because "the opinion went out of its way to suggest that another statute, the Religious Freedom Restoration Act, might prevent Title VII from prohibiting discrimination by employers who have religious objections."); Adam Liptak, Job Bias Laws Do Not Protect Teachers in Catholic Schools, Supreme Court Rules, N.Y. TimEs (July 9, 2020), https://www.nytimes.com/2020/07/08/us/job-bias-catholic-schools-supreme -court.html [https://perma.cc/WYL6-YY8Z] (quoting the ACLU as stating: "[w]hile the Supreme Court has made it clear that it is against the law to fire someone for being L.G.B.T.Q., . . . today they made it easier for religiously affiliated employers to discriminate-including against L.G.B.T.Q. people").

The concerns about RFRA may be overblown. A RFRA defense will only succeed if its proponent shows that the government action at issue substantially burdens a sincere religious belief. See Hobby Lobby, 573 U.S. at 694-95, 719-20. The substantial burden requirement may turn out to be a real brake on the success of RFRA defenses. The Sixth Circuit declined to validate the employer's argument that employing a transgender person substantially burdened its religious belief. See Harris II, 884 F.3d at 588 (holding that "simply permitting Stephens to wear attire that reflects a conception of gender that is at odds with Rost's religious beliefs is not a substantial burden under RFRA" because "as a matter of law, tolerating Stephens's understanding of her sex and gender identity is not tantamount to supporting it"). For an excellent analysis of the application of RFRA defenses to discrimination claims addressing the significant hurdles such defenses will face, see generally Ira C. Lupu, Moving Targets: Obergefell, Hobby Lobby, and the Future of LGBT Rights, 7 ALA. C.R. \& C.L. L. REV. 1 (2015).

290. See sources cited supra note 272.

291. Harris I, 201 F. Supp. 3d 837, 870 (E.D. Mich. 2016) (granting summary judgment in favor of the employer on the wrongful termination claim, finding the Funeral Home was entitled to a RFRA exemption from Title VII).

292. While assuming that the government had stated a compelling interest, the court seriously called into question whether the interest the EEOC asserted-"protecting employees from gender stereotyping in the workplace"-met Hobby Lobby's bar for a compelling interest, which requires considering the "'marginal interest in enforcing' the challenged law in this particular context." Harris I, $201 \mathrm{~F}$. Supp. $3 \mathrm{~d}$ at 859-60 (quoting Burwell v. Hobby Lobby Stores, 573 U.S. 682, 727 (2014)). 
employed the least restrictive means of furthering that interest, and held that it did not. ${ }^{293}$ As discussed earlier, the court could not see how a case in which a transgender person seeks access to rather than challenges a sex-based dress code fights sex stereotypes. ${ }^{294}$ As the court explained:

The EEOC wants Stephens to be able to dress in a stereotypical feminine manner. If the compelling governmental interest is truly in removing or eliminating gender stereotypes in the workplace in terms of clothing (i.e., making gender "irrelevant"), the EEOC's manner of enforcement in this action (insisting that Stephens be permitted to dress in a stereotypical feminine manner at work) does not accomplish that goal. ${ }^{295}$

The court suggested that the EEOC should have instead "challenged the Funeral Home's sex-specific dress code."296

So it was the court's failure to understand how transgender plaintiffs enforce sex discrimination law's aims, even when they seek to conform their gender presentation to their identified sex, that led to the demise of Stephens's claim under RFRA. For this reason, the court suggested that transgender plaintiffs' claims to access sex-based rules rather than challenge them would fail under RFRA. ${ }^{297}$ But challenging sex-based rules or seeking gender-neutral rules ${ }^{298}$ will often not bring relief to transgender plaintiffs, who often seek to confirm their identity by presenting in ways consistent with it. ${ }^{299}$ This underscores how courts are already confused about the wants and needs of transgender persons. ${ }^{300}$ Bostock does nothing to clarify this confusion.

It's possible that Bostock itself will change the analysis of RFRA defenses in these cases. Applying Bostock, the government's

293. Id. at 860 .

294. See id. at 863 (explaining that the EEOC's "position that Stephens must be allowed to wear a skirt-suit in order to express Stephens's female gender identity" amounts to a claim that Stephens "be able to dress in a stereotypical feminine manner"); infra notes 296-98 and accompanying text.

295. Harris I, 201 F. Supp. 3d at 863.

296. Id. at 861.

297. Id. (noting that "the EEOC has not challenged the Funeral Home's sex-specific dress code," and "[i]f the EEOC were truly interested in eliminating gender stereotypes as to clothing in the workplace, it presumably would have attempted to do so").

298. Id. at 861-62 ("If the EEOC truly has a compelling governmental interest in ensuring that Stephens is not subject to gender stereotypes in the workplace in terms of required clothing at the Funeral Home, couldn't the EEOC propose a gender-neutral dress code (dark-colored suit, consisting of a matching business jacket and pants, but without a neck tie) as a reasonable accommodation that would be a less restrictive means of furthering that goal under the facts presented here?").

299. See supra notes 291-93.

300. See Young, supra note 14, at 36-37 (discussing the Justices' confusion about transgender status during the oral argument of Aimee Stephens's case). 
compelling interest in combatting transgender discrimination will no longer be challenging expectations of gender conformity but challenging sex discrimination itself. ${ }^{301}$ But even then, the district court's concern in Stephens's case could still apply: whether seeking access to sex-based rules rather than challenging them furthers the government's compelling interest in fighting sex discrimination. ${ }^{302}$

These legal concerns dovetail with social concerns arising from the Bostock decision. These concerns relate to the place of transgender rights socially: how transgender persons and their rights are viewed, and what this means for solidarity (or lack thereof) between transgender persons and their advocates, on the one hand, and women and their advocates, on the other. While mainstream women's rights groups have typically supported transgender rights, ${ }^{303}$ there has been substantial public attention paid to concerns that transgender rights undermine women's rights. ${ }^{304}$ The boogeyman is the worry (often raised by so-called radical feminists) that cisgender men will assume a false trans identity to invade women's spaces. ${ }^{305}$

But the more pedestrian worry shared by some radical and nonradical feminists alike is that transgender women reinforce rather than fight the type of sex stereotypes that have long held women back. Indeed, there is a history of questioning whether transgender persons further the anti-stereotyping goals of sex discrimination law. ${ }^{306}$ The

301. Harris I, 201 F. Supp. 3d at 861 ("The only reason that the EEOC can pursue a Title VII claim on behalf of Stephens in this case is under the theory that the Funeral Home discriminated against Stephens because Stephens failed to conform to the 'masculine gender stereotypes that Rost expected' in terms of the clothing Stephens would wear at work.").

302. Id.

303. These groups filed an amicus brief in support of Stephens in the Supreme Court. See Brief of the National Women's Law Center and Other Women's Rights Groups as Amici Curiae in Support of the Employees, supra note 15.

304. One of the highest profile voices is Harry Potter author J.K. Rowling, who raised concerns about transgender women in women's spaces. See Tara John, Trans Activists Call J.K. Rowling Essay "Devastating," CNN (June 11, 2020 2:19 PM), https:// www.cnn.com/2020/06/11/uk/jk-rowling-trans-harry-potter-gbr-intl/index.html [https://perma.cc/B2KF-LXFM].

305. Brief of Amicus Curiae Women's Liberation Front in Support of Petitioner, R.G. \& G.R. Harris Funeral Homes, Inc. v. Equal Emp. Opportunity Comm'n., No. 18-107 (U.S. Aug. 20, 2019), 2019 WL 3987628, at*24 ("That any male can justify his presence in any female-only space by saying 'I identify as female' will not escape the notice of those who already harass, assault, and rape tens of thousands of women and girls every day.").

306. See, e.g., Lee, supra note 156, at 445 ("[T]he potential reification of existing gender stereotypes ... is a significant concern."); Kirkland, supra note 6, at 11 (raising concern of reinforcing stereotypes by transgender persons relying on a "mystical 
claim has generally gone that transgender persons' outward presentation and performance of their identified sex often involves an outward appearance and performance of the gender stereotypes associated with that sex, thereby reaffirming those stereotypes. ${ }^{307}$

For example, in an amicus brief in Bostock, the Women's Liberation Front, a radical feminist group, argued that "the ruling below asserts that Aimee Stephens is 'a transgender woman,' based on the notion that Stephens is 'the person that [her] mind already is,' and Stephens' desire to wear clothing designed for women out of a desire to 'live ... as a woman.' The ruling below is, therefore, simply an enshrinement of the discredited 'brain-sex' theories and sex-based stereotypes, which Title VII and this Court's decision in Price Waterhouse intended to abolish." 308 Writing about Caitlyn Jenner, one of the most high-profile transgender persons, Elinor Burkett, a former professor and mainstream figure, described “Jenner's idea of a woman: a cleavage-boosting corset, sultry poses, thick mascara and the prospect of regular 'girls' nights' of banter about hair and makeup," and argued that these presentations "reduce [women] to hoary stereotypes" that have been "used to repress women for centuries." 309

As to the descriptive claim that transgender persons are more gender conforming than cisgender persons, transgender persons represent a range of relationships between sex and gender: some transgender women present as feminine, while others do not; some transgender men present as masculine, while others do not. ${ }^{310}$ But it may well be that, on average, transgender persons tend to be more

union of sex and gender"). Some scholars have blamed this on flaws in the gender nonconformity doctrine. See Andrew Gilden, Toward a More Transformative Approach: The Limits of Transgender Formal Equality, 23 BERKELEY J. GENDER L. \& JUST. 83, 92 (2008) ('In describing a 'biologically male' transsexual as performing feminine acts, it furthers the construction of particular acts as inherently feminine and normatively conflated with biological femaleness."); Lee, supra note 156, at 444 (discussing scholarship critiquing the gender nonconformity doctrine for recapitulating sex stereotypes by restating them).

307. See sources cited supra notes 288-89.

308. Brief of Amicus Curiae Women's Liberation Front, supra note 308, at*18.

309. Elinor Burkett, What Makes a Woman?, N.Y. Times (June 7, 2015), https:// www.nytimes.com/2015/06/07/opinion/sunday/what-makes-a-woman.html [https://perma.cc/RJ6V-FTFB]; see also Samantha Allen, Caitlyn Jenner Is Pissing Off Feminists and Bigots-Good for Her, DAILY BEAST (June 9, 2015, 1:45 PM), https://www .thedailybeast.com/caitlyn-jenner-is-pissing-off-feminists-and-bigotsgood-for-her [https://perma.cc/7LFT-QVK2] (cataloguing feminist complaints along these lines, including that "Jenner is undoing [the] hard work" of feminists to fight against "stereotypes").

310. See Vade, supra note 259, at 260 ("[S] ome male-to-female transgender people are butch lesbians. Some female-to-male transgender people like to cook and bake."). 
gender conforming than cisgender persons. If this is so, there may be good reasons for it. Transgender persons may have strong gender associations that make cross-gender manifestations especially painful. 311 Many transgender persons endure substantial hardships to express their identified sex, and thus the ability to adopt "a single identity within the binary may therefore be very important." 312 And retaining existing sex binaries may be more important to transgender persons "because faithful adherence to those constructs enables [them] to pass [as their identified sex]."313

Even if it is the case that transgender persons are more likely to adopt stereotypical representations of their sex than cisgender persons, this does not mean that transgender persons do not fight sex stereotypes. At least some of the resistance to the notion that persons can change the sex they were designated at birth is based in sex stereotypes, particularly when a transgender person's gender performance was seen to conform strongly to the sex he or she was designated at birth. ${ }^{314}$ By fighting this resistance that is grounded in sex stereotypes, transgender plaintiffs do further the traditional goals of sex discrimination law. ${ }^{315}$

Take Bostock itself. In that case, Stephens's employer objected to her being transgender and the notion that she could change her sex designated at birth because of sex stereotypes. ${ }^{316}$ Stephens was designated male at birth, yet identified as a woman. ${ }^{317}$ The employer complained that "a woman should look like a woman," 318 and that the employee was too masculine to be a woman because she had been designated male at birth. ${ }^{319}$ In the employer's mind, even though he

311. See Yuracko, supra note 14, at 801 (suggesting that " $[\mathrm{t}]$ ranssexuals may experience gender more acutely than nontranssexuals" and that "[n]ontranssexuals may have weaker gender commitments than transsexuals").

312. Lee, supra note 156, at 460 (internal quotation marks omitted).

313. Id.; see also Yuracko, supra note 14, at 801-02 ("Transsexuals may find that highly traditional outward gender manifestations are critically important to their gender identity because they simply cannot be recognized as their true gender unless their outward manifestations of gender are clear, strong, and uniform. Nontranssexuals may have much less difficulty having their gender recognized even if they send a range of more mixed and ambivalent signals through their outward manifestations-clothes, hair, makeup, jewelry, etc.").

314. See, e.g., infra note 326 and accompanying text.

315. See supra notes 1-4 and accompanying text.

316. Bostock v. Clayton Cnty., 140 S. Ct. 1731, 1738 (2020); see Brief for Respondent Aimee Stephens, supra note 11, at 49.

317. Brief for Respondent Aimee Stephens, supra note 11, at 49.

318. Id. at 11.

319. Id. at 30-31. 
had never seen the employee present herself as a woman, he knew she was too masculine to be a woman simply because the employee had been designated male at birth: "I've yet to see a man dressed up as a woman that I didn't know was not a man dressed up as a woman," and therefore "there is no way that" Ms. Stephens "would be able to present in such a way that it would not be obvious that it was [a man]." 320 In other words, a person who is designated male at birth cannot be considered a woman because she is too masculine. This way of thinking evidences two forms of impermissible sex stereotyping: that a person who is designated male at birth is inherently masculine, and that a person designated female must display a certain sort of femininity. 321

We can see this sort of sex stereotyping logic at play in transgender cases more broadly. Consider the Schroer case. ${ }^{322}$ The plaintiff there, a transgender person who was designated male at birth and who identified as female, had an extensive military background. 323 The employer decision maker testified that "she was puzzled by the idea that 'someone [could] go [] through the experience of Special Forces [and] decide that he wants to become a woman." 324 The employer's trouble with the plaintiff's transgender status stemmed precisely from the type of sex stereotype that sex discrimination law aims to combat: that a woman would not want to engage in stereotypically masculine endeavors.

Opposition to Caitlyn Jenner can be understood in these terms, too. Jenner has been a prime target of concerns about reinforcing sex stereotypes. ${ }^{325}$ Some of the resistance to Jenner's living as a woman was due to the fact that Jenner, who had been an Olympic champion when presenting as a man, was the literal embodiment of classic

320. Id. at $9-10$.

321. See Price Waterhouse v. Hopkins, 490 U.S. 228, 251 (1989) (holding that "we are beyond the day when an employer could evaluate employees by assuming or insisting that they matched the stereotype associated with their group").

322. Schroer v. Billington, 577 F. Supp. 2d 293, 298 (D.D.C. 2008).

323. Id.

324. See id. at 305 ("Preece testified that her difficulty comprehending Schroer's decision to undergo a gender transition was heightened because she viewed David Schroer not just as a man, but, in light of her Special Forces background, as a particularly masculine kind of man.").

325. See Burkett, supra note 309 and accompanying text. 
masculine virtues of strength and athleticism. ${ }^{326}$ It was hard for some to accept that such a masculine person could be a woman. ${ }^{327}$

Transgender discrimination thus can be based on the notion that a masculine person could not be a woman or that a feminine person could not be a man. In other words, the discrimination is based on the notion that a woman cannot be masculine or that a man cannot be feminine. The same stereotypes about gender conformity are at play, but in reverse: that sex should conform to gender, rather than that gender should conform to sex. In this way, recognizing transgender discrimination as sex discrimination precisely furthers the aims of the anti-stereotyping thrust of American sex discrimination law. ${ }^{328}$

Responding to the legal and social concerns arising from Bostock's failure to address the reality of transgender discrimination as a practice of sex discrimination requires courts and commentators to make clear what Bostock did not: how transgender persons fight sex stereotypes in the same way as traditional victims of sex discrimination because transgender discrimination is motivated by the same sorts of sex stereotypes that have long been recognized to hold women and men back on the basis of their sex. I have begun to take up this project in this Article and elsewhere, ${ }^{329}$ and call on other commentators and courts to join me.

\section{CONCLUSION}

While transgender discrimination can and should be deemed sex discrimination, the new law of gender nonconformity sent courts down the wrong path in arriving at this conclusion. In applying the gender nonconformity theory, perhaps well-meaning courts seeking to find a way to protect transgender plaintiffs nonetheless did a disservice, not only to transgender rights and transgender identity, but

326. Editorial, From Bruce to Caitlyn: When "the Total Man" Becomes a Woman, CHI. TRIB. (June 10, 2015, 4:53 PM), https://www.chicagotribune.com/opinion/editorials/ ct-jenner-caitlyn-bruce-transgender-understanding-20150610-story.html (describing Jenner as "[t]he total man, body and spirit" and noting that Jenner was "seen by the world as the definition of masculinity"); Rebecca Mead, Caitlyn Jenner's Big Debut, NEw YORKER (June 2, 2015), https://www.newyorker.com/culture/cultural-comment/ caitlyn-jenners-big-debut [https://perma.cc/CP7Q-BR9F] (“[A]s the athlete Bruce Jenner, she was a gold medalist at the 1976 Olympic Games, the apotheosis of masculinity.").

327. Editorial, supra note 326 ("We don't yet know Caitlyn Jenner, but we know Bruce Jenner very well, and the contrast between Jenner the male athlete and Jenner the female TV star is so extreme that we're left boggled.").

328. See supra notes 38-43 and accompanying text.

329. See Schoenbaum, supra note 32. 
to protection for gender nonconformity more generally. The gender nonconformity doctrine falls short because it confuses sex and gender and fundamentally misunderstands what it means to be transgender.

The Court began to correct this error with its decision in Bostock v. Clayton County. ${ }^{330}$ There, the Court recognized discrimination on the basis of transgender status to be discrimination on the basis of sex under federal employment discrimination law without relying on the gender nonconformity theory. In that regard, the decision is a big victory, both for providing nationwide protection for transgender rights in the workplace, and for doing so while avoiding the serious harms sowed by the gender nonconformity theory. This decision may mark the beginning of the end of the new law of gender nonconformity.

But the Bostock decision was an incomplete corrective to the problems of the new law of gender nonconformity. Its thin formal analysis fails to connect transgender discrimination to long-recognized forms of sex discrimination that are core to sex discrimination law's anti-stereotyping aims. This separation of transgender discrimination from sex discrimination brings its own costs, in terms of transgender discrimination claims' vulnerability to religious freedom defenses and social solidarity between transgender rights and women's rights. So while the possible fall of the new law of gender nonconformity is a welcome development, what rises in its place is equally important. It is critical that courts and commentators develop a rich account of how bringing transgender discrimination within the fold of sex discrimination furthers the historic role of sex discrimination law in bringing an end to sex stereotypes.

330. 140 S. Ct. 1731 (2020). 